\title{
Emerging Mechanisms and Treatment Progress on Liver Metastasis of Colorectal Cancer
}

\author{
Wubin Zheng ${ }^{1, *}$ \\ Fan $\mathrm{Wu}^{\mathrm{l}, *}$ \\ Kai Fu',* \\ Guangshun Sun' \\ Guoqiang Sun' \\ Xiao Li (D) \\ Wei Jiang' \\ Hongyong Cao' \\ Hanjin Wang' \\ Weiwei Tang ${ }^{2}$ \\ 'Department of General Surgery, Nanjing \\ First Hospital, Nanjing Medical University, \\ Nanjing, People's Republic of China; \\ ${ }^{2}$ Hepatobiliary/Liver Transplantation \\ Center, The First Affiliated Hospital of \\ Nanjing Medical University, Key \\ Laboratory of Living Donor \\ Transplantation, Chinese Academy of \\ Medical Sciences, Nanjing, People's \\ Republic of China \\ *These authors contributed equally to \\ this work
}

\begin{abstract}
Colorectal cancer is currently the third largest malignant tumor in the world, with high new cases and high mortality. Metastasis is one of the most common causes of death of colorectal cancer, of which liver metastasis is the most fatal. Since the beginning of the Human Genome Project in 2001, people have gradually recognized the 3 billion base pairs that make up the human genome, of which only about $1.5 \%$ of the nucleic acid sequences are used for protein coding, including proto-oncogenes and tumor suppressor genes. A large number of differences in the expression of proto-oncogenes and tumor suppressor genes have also been found in the study of colorectal cancer, which proves that they are also actively involved in the progression of colorectal cancer and promote the occurrence of liver metastasis. Except for $1.5 \%$ of the coding sequence, the rest of the nucleic acid sequence does not encode any protein, which is called non-coding RNA. With the deepening of research, genome sequences without protein coding potential that were originally considered "junk sequences" may have important biological functions. Many years of studies have found that a large number of abnormal expression of ncRNA in colorectal cancer liver metastasis, indicating that ncRNA plays an important role in it. To explore the role and mechanism of these coding sequences and non-coding RNA in liver metastasis of colorectal cancer is very important for the early diagnosis and treatment of liver metastasis of colorectal cancer. This article reviews the coding genes and ncRNA that have been found in the study of liver metastasis of colorectal cancer in recent years, as well as the mechanisms that have been identified or are still under study, as well as the clinical treatment of liver metastasis of colorectal cancer.
\end{abstract}

Keywords: colorectal cancer, liver metastasis, mechanisms, treatment

\section{Introduction}

Colorectal cancer has about 1.4 million new cases and 694,000 deaths worldwide every year, making it the third largest malignant tumor in the world. ${ }^{1,2}$ Metastasis is the most common cause of death from colorectal cancer, while liver metastasis is the most common. ${ }^{3-5}$ Some studies have shown that liver metastasis accounts for $75-83 \%$ of colorectal cancer metastasis. ${ }^{6,7}$ Therefore, the early diagnosis of liver metastasis of colorectal cancer is very important to reduce the mortality of patients. Due to the lack of sensitivity and specificity of serum markers such as CEA, in the diagnosis of colorectal cancer liver metastasis, the diagnosis of colorectal cancer liver metastasis still depends on imaging examination and focus biopsy. ${ }^{8-10}$ However, the sensitivity of imaging diagnosis of liver metastasis of colorectal cancer is still insufficient to achieve the effect of early diagnosis, so it is imperative to find a new biomarker that can better diagnose liver metastasis of colorectal cancer.
Correspondence: Hongyong Cao; Hanjin Wang

Email caohongy6167@I63.com

wanghanjin197I@I63.com 
The mechanism of liver metastasis of colorectal cancer has not been fully elucidated. Current studies have shown that tumor cells spread from primary to distant organs and develop into metastatic foci, which is a continuous dynamic process with the participation of multiple genes and multiple links. It involves many links, such as tumor cell adhesion, invasion, extracellular matrix remodeling, neovascularization and lymphangiogenesis, body immunity and so on. ${ }^{11}$ In recent years, the relationship between abnormal expression of tumor genes and liver metastasis of colorectal cancer has become the focus of tumor molecular biology research, and made a breakthrough. Liver metastasis of colorectal cancer must have two prerequisites: first, colon cancer cells themselves have high metastatic characteristics; second, there must be target organs suitable for the growth of metastatic colon cancer cells. Thus, it can be seen that a large number of mutations of oncogenes or tumor suppressor genes make colon cancer cells easy to metastasize, and the liver is an organ suitable for the growth of metastatic colon cancer cells, both of which promote liver metastasis of colorectal cancer and lead to poor prognosis.

Over the past 10 years, with the development of next generation sequencing and bioinformatics, there has been a great variety. Thousands of Non-coding RNA has been discovered. In a sense, only the open reading frame (ORF) sequence on mRNA is the "coding" sequence, while other sequences on mRNA and a large number of non-mRNA transcripts that can not be used as translation templates are called non-coding RNA sequences. ${ }^{12-14}$ The non-coding RNA sequence on mRNA can regulate the translation, location and stability of mRNA. ${ }^{15-20}$ More and more evidence shows that ncRNA plays an important role in the occurrence, development and metastasis of colorectal cancer. It can be used not only as a tumor suppressor, but also as an oncogene to regulate the expression of its specific mRNA target. ${ }^{21-26}$

In this review, we summarize the research progress of coding genes and non-coding RNAs in colorectal liver metastasis, and briefly introduce the progress in clinical treatment in recent years. It is expected to contribute to the early detection and early treatment of liver metastasis of colorectal cancer, and to prolong the survival time and quality of life of patients.

\section{Brief Overview of Coding Genes}

Malignant tumor causes serious harm to human health, and its occurrence is the result of the joint action of multi- factors, multi-stages and multi-genes, which is closely related to the disturbance of cell cycle and apoptosis regulation. In the occurrence and development of tumor, when various environmental factors and genetic pathogenic factors cause DNA damage, thus activating protooncogenes and inactivating tumor suppressor genes, resulting in disturbance of cell cycle regulation and imbalance of apoptosis regulation, resulting in abnormal cell growth, is the most fundamental cause of tumorigenesis. We sorted out the coding genes and their products that have been found in the research of colorectal cancer liver metastasis (CRLM) in recent years, and briefly worked out the mechanism in Table 1.

\section{The Role of Tumor Suppressor Genes in Liver Metastasis of Colorectal Cancer}

Tumor suppressor genes are a kind of genes that exist in normal cells which can inhibit cell growth and have potential anti-tumor effect. Tumor suppressor genes play a very important negative regulatory role in controlling cell growth, proliferation and differentiation. They restrict each other with proto-oncogenes and maintain the relative stability of positive and negative regulatory signals. When these genes are mutated, deleted or inactivated, they can cause malignant transformation of cells and lead to tumorigenesis. So far, scientists have isolated and identified about 100 kinds of tumor suppressor genes from cells, the most common of which are Rb, p53, APC, nm23 and so on. According to whether there is a mutation, it can be divided into two types: mutant type and wild type, and according to different acting organs, it can be divided into broad spectrum and specificity. Different tumor suppressor genes have different functions. Some of them can participate in cell signal transduction and epigenetic regulation, some can negatively regulate cell cycle, some can lead to DNA mismatch repair, some can regulate development and stem cell proliferation, and some can be used as negative transcriptional factors. These functions can participate in the occurrence and development of tumor. In CRLM, some tumor suppressor genes are also involved and play an irreplaceable role. The abnormally expressed tumor suppressor genes found in CRLM in recent years were sorted out in Table 1.

\section{PTEN}

PTEN gene (phosphatase and tensin homologue deleted on chromosome 10), also known as advanced tumor mutant gene, is the first tumor suppressor gene with dual specific 
Table I Coding Genes in Liver Metastasis of Colorectal Cancer

\begin{tabular}{|c|c|c|c|}
\hline Genes & Major Effects & $\begin{array}{l}\text { Receptors/ } \\
\text { Inhibitor }\end{array}$ & Reference \\
\hline CXCL8 & $\begin{array}{l}\text { CXCL8 and its receptors have also been known to induce the epithelial-mesenchymal } \\
\text { transition (EMT) of CRC cells, to help them to escape host immunosurveillance as well as to } \\
\text { enhance resistance to anoikis, which promotes the formation of circulating tumor cells } \\
\text { (CTCs) and their colonization of distant organs. }\end{array}$ & $\begin{array}{l}\text { CXCRI, CXCR2, } \\
\text { DARC }\end{array}$ & [60] \\
\hline HMGA2 & $\begin{array}{l}\text { By forming a circNSUN2/IGF2BP2/HMGA2 RNA-protein ternary complex in the cytoplasm, } \\
\text { circNSUN2 enhances the stability of HMGA2 mRNA to promote CRC metastasis } \\
\text { progression. }\end{array}$ & circNSUN2 & {$[108]$} \\
\hline GATA6 & $\begin{array}{l}\text { Via GATA6, metastatic cells in the liver upregulate the enzyme aldolase B (ALDOB), which } \\
\text { enhances fructose metabolism and provides fuel for major pathways of central carbon } \\
\text { metabolism during tumor cell proliferation. }\end{array}$ & ALDOB & [124] \\
\hline CXCR4 & $\begin{array}{l}\text { CXCR4/TGF- } \beta \text { I axis plays an important role in CRC liver metastasis through mediating HSCs } \\
\text { differentiation into CAFs. }\end{array}$ & TGF- $\beta$ I & [59] \\
\hline DC-SIGNR & $\begin{array}{l}\text { DC-SIGNR conferred metastatic capability on cancer cells by upregulating various } \\
\text { metallothionein isoforms. }\end{array}$ & - & [125] \\
\hline IGFBP7 & IGFBP7 may prevent colon cancer metastasis by inhibiting EMT. & - & [126] \\
\hline PRRX2 & $\begin{array}{l}\text { PRRX2 inhibition may reduce invasive and migrating abilities to hinder epithelial-mesenchymal } \\
\text { transition (EMT), and suppress colon cancer liver metastasis through inactivation of Wnt/ } \beta \text { - } \\
\text { catenin pathway. }\end{array}$ & $\begin{array}{l}\text { Wnt } / \beta \text {-catenin } \\
\text { signaling pathway }\end{array}$ & [127] \\
\hline KRAS & $\begin{array}{l}\text { Amplification of ERKI/2 signaling in KRAS-mutated colorectal cancer cells affects the cytokine } \\
\text { milieu of the tumors, possibly affecting tumor-stroma interactions and favoring liver metastasis } \\
\text { formation. }\end{array}$ & ERKI/2 signaling & [128] \\
\hline PTGIS & $\begin{array}{l}\text { PTGIS expression and lymph node metastasis are independent risk factors for liver metastasis } \\
\text { of colon cancer. }\end{array}$ & - & [129] \\
\hline Gli-I & $\begin{array}{l}\text { Gli-I is significantly up-regulated in colon cancer, which may be closely related to liver } \\
\text { metastasis. The mechanism is not clear. }\end{array}$ & - & {$[130]$} \\
\hline WTp53 & $\begin{array}{l}\text { WTp53 has synergistic effect with TK/GCV and CD/5-FC, which can effectively inhibit the } \\
\text { formation of liver metastasis of colon cancer. }\end{array}$ & - & [33] \\
\hline CXCLI & $\begin{array}{l}\text { TSU68 can significantly reduce the expression of CXCLI in colon cancer with liver } \\
\text { metastasis. }\end{array}$ & TSU68 & {$[|3|]$} \\
\hline VEGF & \multirow{2}{*}{$\begin{array}{l}\text { The high levels of VEGF and TIMP-I were found to be significant predictive factors for poor } \\
\text { prognosis following liver resection. }\end{array}$} & \multirow[t]{2}{*}{-} & \multirow[t]{2}{*}{ [132-135] } \\
\hline TIMP-I & & & \\
\hline SDF-I & $\begin{array}{l}\text { Arrest of CXCR4 can inhibit liver metastasis of colon cancer through blocking cell } \\
\text { proliferation and migration induced by SDF-I. }\end{array}$ & CXCR4 & [136] \\
\hline Galectin-3 & The expression of galetin-3 is significantly increased in the liver metastasis of colon cancer. & - & [137] \\
\hline TROP2 & $\begin{array}{l}\text { TROP2 is highly expressed in liver metastatic cells of colorectal cancer and significantly } \\
\text { reduces the survival time. }\end{array}$ & - & [138] \\
\hline NK4 & $\begin{array}{l}\text { Hepatic gene expression of NK4 inhibited the liver metastasis and subsequent growth } \\
\text { associated with a decrease in microvessel density. }\end{array}$ & - & [139] \\
\hline TFF3 & $\begin{array}{l}\text { TFF } 3 \text { is highly expressed in liver metastasis of human colon cancer and increases the ability of } \\
\text { invasion and metastasis. }\end{array}$ & - & {$[140]$} \\
\hline
\end{tabular}


Table I (Continued).

\begin{tabular}{|c|c|c|c|}
\hline Genes & Major Effects & $\begin{array}{l}\text { Receptors/ } \\
\text { Inhibitor }\end{array}$ & Reference \\
\hline TIMP-I & $\begin{array}{l}\text { High expression of TIMP-I can effectively combat MMPs, in tumor tissue and inhibit liver } \\
\text { metastasis of colon cancer. }\end{array}$ & MMPs & {$[14 \mid]$} \\
\hline FAS & FAS is highly expressed in liver metastatic tumor cells of colon cancer. & - & [142] \\
\hline SLeX & $\begin{array}{l}\text { Cancer cells expressing SLeX can adhere to hepatic sinusoidal endothelial cells treated with } \\
\text { IL-I } \beta \text { through SLeX- selectin interaction system, which may be the first step in the metastasis } \\
\text { of colon cancer cells to liver. }\end{array}$ & IL-I $\beta$ & [143] \\
\hline PRDX4 & \multirow{4}{*}{$\begin{array}{l}\text { High expression of PRDX4, CKS2, MAGED2 and EST in Colorectal Cancer with liver } \\
\text { Metastasis }\end{array}$} & \multirow[t]{4}{*}{-} & \multirow[t]{4}{*}{ [144] } \\
\hline CKS2 & & & \\
\hline MAGED2 & & & \\
\hline EST & & & \\
\hline CCRI & \multirow{3}{*}{$\begin{array}{l}\text { Lack of the CCRI, MMP2, MMP9 gene in the host dramatically suppresses outgrowths of } \\
\text { disseminated colon cancer in the liver }\end{array}$} & \multirow[t]{3}{*}{ CCL9, CCLI5 } & \multirow[t]{3}{*}{ [145-147] } \\
\hline MMP2 & & & \\
\hline MMP9 & & & \\
\hline PA & $\begin{array}{l}\text { PALS can inhibit the expression of PA and has an inhibitory effect on colorectal liver } \\
\text { metastasis }\end{array}$ & PALS & [148] \\
\hline TGF- $\beta$ & Promote tumor growth, invasion and metastasis in in liver metastasis of colon cancer & LY2I0976I & [149] \\
\hline STRAIL & $\begin{array}{l}\text { STRAIL and actinomycin D can synergistically inhibit multiple intrahepatic metastasis of } \\
\text { TRAIL-resistant colon cancer }\end{array}$ & - & [150] \\
\hline EMX2 & $\begin{array}{l}\text { The decreased expression of EMX } 2 \text { promotes distant liver metastasis and reduces the survival } \\
\text { rate of colorectal cancer, but the exact mechanism is still unknown }\end{array}$ & - & [151] \\
\hline THBS-I & $\begin{array}{l}\text { Low expression of THBS-I promotes liver Metastasis of Colorectal tumor and EMT, may be } \\
\text { regulated by HIF-I Pathway }\end{array}$ & HIF-I & [152] \\
\hline Integrin $\beta 4$ & \multirow{2}{*}{$\begin{array}{l}\text { ZKSCAN3 can promote the expression of integrin } \beta 4 \text { and VEGF, which may promote the } \\
\text { liver metastasis of CEA related colorectal cancer, especially in the cases of CEA tumor. }\end{array}$} & \multirow[t]{2}{*}{ ZKSCAN3 } & \multirow[t]{2}{*}{ [153] } \\
\hline VEGF & & & \\
\hline SNCG & $\begin{array}{l}\text { High expression of SNCG is present in the tumor tissue in patients with liver metastasis from } \\
\text { colorectal cancer. The mechanism is not clear. }\end{array}$ & - & {$[54]$} \\
\hline TBLIXRI & $\begin{array}{l}\text { For stage IV CRC patients, TBLIXRI expression was correlated with the number of liver } \\
\text { metastases, and high levels of TBLIXRI in liver metastases indicated poor overall survival. }\end{array}$ & - & [154] \\
\hline Smad4 & $\begin{array}{l}\text { Knockdown of Smad4 ERK pathway, altered the expression of MMP2 and COX-2, promoted } \\
\text { cell motility, migration, and invasion in vitro, enhanced metastasis. }\end{array}$ & ERK pathway & [155] \\
\hline Fbxw7 & $\begin{array}{l}\text { Fbxw7 expression in tumor tissues was significantly lower than that in normal tissues, miR- } \\
223 \text { might be a possible regulator of Fbxw7. }\end{array}$ & $\operatorname{miR}-223$ & [156] \\
\hline АPOBECЗG & $\begin{array}{l}\text { APOBEC3G promotes colorectal cancer hepatic metastasis through inhibition of miR-29- } \\
\text { mediated suppression of MMP2. }\end{array}$ & $\begin{array}{l}\operatorname{miR}-29 \\
\text { MMP2 }\end{array}$ & [157] \\
\hline AEG-I & $\begin{array}{l}\text { The expression of AEG-I protein was significantly increased in tumor cells with liver } \\
\text { metastasis. }\end{array}$ & - & [158] \\
\hline DVLI & DVLI is significantly overexpressed in CRC patients with liver metastasis. & - & [159] \\
\hline
\end{tabular}


Table I (Continued).

\begin{tabular}{|c|c|c|c|}
\hline Genes & Major Effects & $\begin{array}{l}\text { Receptors/ } \\
\text { Inhibitor }\end{array}$ & Reference \\
\hline Claudin I & \multirow{2}{*}{$\begin{array}{l}\text { Claudin I and claudin } 4 \text { gene knockout can significantly promote tumor cell migration and } \\
\text { inhibit clonal growth, and reduce the overall survival rate. }\end{array}$} & \multirow[t]{2}{*}{ - } & \multirow[t]{2}{*}[160]{} \\
\hline Claudin 4 & & & \\
\hline USP22 & $\begin{array}{l}\text { The expression level of USP22 in primary cancer tissue and liver metastatic carcinoma was } \\
\text { significantly increased. }\end{array}$ & - & {$[161]$} \\
\hline $\mathrm{MACCl}$ & $\mathrm{MACCI}$ expression level might play an important role in colon cancer invasion. & - & [162] \\
\hline SIOOB & \multirow{3}{*}{$\begin{array}{l}\text { The expression of SI00B and TM4SF4, OLFM4 genes in liver metastatic tumor cells of colon } \\
\text { cancer was significantly up-regulated. }\end{array}$} & \multirow[t]{3}{*}{-} & \multirow[t]{3}{*}[163]{} \\
\hline TM4SF4 & & & \\
\hline OLFM4 & & & \\
\hline CCL7 & $\begin{array}{l}\text { The expression of CCL7 genes in liver metastatic tumor cells of colon cancer was significantly } \\
\text { up-regulated. }\end{array}$ & - & {$[164]$} \\
\hline PSMA7 & $\begin{array}{l}\text { The expression of PSMA7 in liver metastases is significantly higher than that in primary lesions } \\
\text { and lymph nodes, suggesting that PSMA7 may play an important role in the development of } \\
\text { colorectal cancer. }\end{array}$ & - & {$[165]$} \\
\hline HGF & $\begin{array}{l}\text { HGF is highly expressed in colorectal cancer with liver metastasis. HGF-c-Met may play a role } \\
\text { in colorectal cancer with regional lymph node metastasis. }\end{array}$ & c-Met & {$[166]$} \\
\hline SIOOAG & $\begin{array}{l}\text { SI00A6 is involved in the invasion of colorectal adenocarcinoma and its expression level } \\
\text { decreases in liver metastases. }\end{array}$ & - & {$[167]$} \\
\hline PRL-3 & \multirow{2}{*}{$\begin{array}{l}\text { PRL-3 and c-myc genomic gain may represent an aggressive phenotype of primary CRC, and } \\
\text { may associate with liver metastasis. }\end{array}$} & \multirow[t]{2}{*}{ - } & \multirow[t]{2}{*}[168,169]{} \\
\hline c-myc & & & \\
\hline $\begin{array}{l}\text { CRPSNP } \\
\text { rs7553007 }\end{array}$ & \multirow{2}{*}{$\begin{array}{l}\text { The mutation rates of CRPSNP rs } 7553007 \text { and KRAS/BRAF genes were significantly increased } \\
\text { in patients with colorectal cancer complicated with liver metastasis, and cooperated with } \\
\text { C-reactive protein to promote liver metastasis. }\end{array}$} & \multirow[t]{2}{*}{-} & \multirow[t]{2}{*}{ [170] } \\
\hline BRAF & & & \\
\hline ZFP57 & $\begin{array}{l}\text { The expression of ZFP57 in tumor cells with liver metastasis was significantly higher than that } \\
\text { in tumor cells without liver metastasis, and the overexpression of ZFP57 decreased the } \\
\text { progression-free survival rate. }\end{array}$ & - & {$[17 \mid]$} \\
\hline PIK3CA & \multirow{2}{*}{$\begin{array}{l}\text { Colon cancer patients with PIK3CA and PTEN gene mutations have a significantly higher rate } \\
\text { of liver metastasis and a poor prognosis. }\end{array}$} & \multirow[t]{2}{*}{-} & \multirow[t]{2}{*}[172]{} \\
\hline PTEN & & & \\
\hline Ereg & \multirow{4}{*}{$\begin{array}{l}\text { Ereg, AREG, COX-2, LCK are closely related to liver metastasis of colorectal cancer and can } \\
\text { be used to predict liver metastasis of colorectal cancer. }\end{array}$} & \multirow[t]{4}{*}{-} & \multirow[t]{4}{*}{ [173] } \\
\hline AREG & & & \\
\hline COX-2 & & & \\
\hline LCK & & & \\
\hline DYRK2 & $\begin{array}{l}\text { In the model of xenotransplantation in vivo, the ectopic expression of DYRK2 significantly } \\
\text { reduced the focus of liver metastasis, and the overall and disease-free survival rate of patients } \\
\text { with liver metastasis with low expression of DYRK2 was significantly poor. }\end{array}$ & - & [174] \\
\hline SIPRI & $\begin{array}{l}\text { The up-regulation of SIPRI expression is closely related to the deep invasion and } \\
\text { metachronous liver metastasis. }\end{array}$ & - & {$[175]$} \\
\hline
\end{tabular}


Table I (Continued).

\begin{tabular}{|c|c|c|c|}
\hline Genes & Major Effects & $\begin{array}{l}\text { Receptors/ } \\
\text { Inhibitor }\end{array}$ & Reference \\
\hline CXCLI6 & $\begin{array}{l}\text { Chemokine CXCLI6 suppresses liver metastasis of colorectal cancer via augmentation of } \\
\text { tumor-infiltrating natural killer T cells. }\end{array}$ & NKT cells & {$[176]$} \\
\hline HNF4 $\alpha$ & $\begin{array}{l}\text { The expression of HNF4 } \alpha \text { was significantly down-regulated in many kinds of tumor cells and } \\
\text { in liver metastatic cells of colon cancer, suggesting that HNF4 } \alpha \text { has the effect of inhibiting } \\
\text { liver metastasis. }\end{array}$ & - & [177] \\
\hline IGF-IR & $\begin{array}{l}\text { Mutant KRAS transcriptionally activates IGF-IR gene expression through Y-box-binding } \\
\text { protein (YB)-I upregulation via a novel MEK-SpI-DNMTI-miR-I } 37 \text { pathway in CRC cells. }\end{array}$ & KRAS & {$[178,179]$} \\
\hline $\mathrm{CD} \times 2$ & $\begin{array}{l}\text { CDX2 participates in the expression of DNA repair protein through Wnt signal transduction } \\
\text { and leads to methylation. The loss of CDX2 expression is an important mechanism of liver } \\
\text { metastasis in colorectal cancer. }\end{array}$ & $\begin{array}{l}\text { Wnt signal } \\
\text { transduction }\end{array}$ & {$[180]$} \\
\hline
\end{tabular}

phosphatase activity cloned from primary breast cancer, prostate cancer and glioblastoma cell lines in $1997 .{ }^{27}$ The anti-tumor effect of PTEN is mainly through MAPK pathway, PI3K/Akt pathway, FAK pathway and cell cycle pathway to participate in normal cell development and inhibit angiogenesis. The subcellular localization of PTEN is very important for its normal cellular function and its role as a tumor suppressor. In colorectal cancer, the mutation rate of PTEN gene is $6 \%$, indicating that PTEN also has a high mutation rate in CRLM. In the cytoplasm, PTEN binds with its cytoplasmic targets to regulate cell proliferation, apoptosis, cell cycle progression, cell adhesion, migration and invasion. In the nucleus, PTEN plays a role in maintaining chromosome stability and DNA double-strand break repair, thus maintaining the integrity of the genome. ${ }^{28}$ The mislocalization of PTEN between nucleus and cytoplasm may lead to malignant growth. ${ }^{29}$ Therefore, the subcellular localization of PTEN is closely regulated and a variety of regulatory mechanisms have been found.

$\mathrm{PI} 3 \mathrm{~K} /$ Akt signaling pathway is an important intracellular signal transduction pathway, which plays an important biological role in cell apoptosis, survival, proliferation and cytoskeleton changes. Its regulation disorder is closely related to the occurrence and development of tumor. Receptor tyrosine kinase (RTK) is the main upstream regulator of PI3K/Akt signal. PTEN is the main antagonist of $\mathrm{PI} 3 \mathrm{~K}$ and a negative regulator of this pathway. Inactivation of PTEN will lead to excessive activation of RTK/PI3K/Akt signal in many tumor types, thus driving tumorigenesis. ${ }^{30}$

Related studies found that in CRLM, the mutation rate of PTEN gene increased significantly, and suggested that the prognosis is obviously poor, PTEN gene may also be involved in liver metastasis through the above mechanism, but the related research has not yet been carried out, we can know the next research direction.

\section{WTp53}

P53 gene is a tumor suppressor gene, located on the short arm of chromosome 17 p. $20 \mathrm{~kb}$, encodes a tumor suppressor protein Tp53, with a molecular weight of $53 \mathrm{kD}$, which is involved in the control of a variety of cell events, such as cell cycle regulation, apoptosis, cell senescence, DNA repair, cell differentiation, gene amplification, DNA recombination, chromosome segregation and angiogenesis. P53 gene can be divided into wild type (WTp53) and mutant type (MTp53). The anti-tumor effect of WTp53 mainly prevents cells from entering $S$ phase in $\mathrm{G} 1 / \mathrm{G} 0$ phase, which inhibits cell proliferation and induces cell apoptosis. ${ }^{31}$ When the p53 gene is mutated, the stable protein can not inhibit the cell proliferation, promote the malignant transformation of the cell, enhance the invasiveness, and make the p53 gene change from tumor suppressor gene to proto-oncogene.

The occurrence of liver metastasis of colorectal cancer is mainly caused by reflux of portal vein and hepatic artery, in which the formation of tumor neovascularization is very important. ${ }^{32} \mathrm{Du} \mathrm{T}$ found that WTp53 has a synergistic effect with $\mathrm{TK} / \mathrm{GCV}$ and $\mathrm{CD} / 5-\mathrm{FC}$ to inhibit tumor neovascularization and prevent liver metastasis. ${ }^{33}$

\section{Claudin}

In humans and animals, there is a tight junction between adjacent epithelial or endothelial cells. Tight junction is one of the main forms of cell adhesion. It is 
a macromolecular complex composed of cytoplasmic proteins and transmembrane proteins. It is the structural and functional basis of paracellular material transport pathways. It mainly has barrier and screening functions, which can maintain the stability of the internal environment of the body and maintain the polarity of epithelial cells. It plays an important role in the normal physiological process of cells. Claudins is a cytoskeleton protein of tight junction between cells and an important component of tight junction molecules. Its abnormal expression can lead to structural damage and functional damage of epithelial cells and endothelial cells, and then lead to tumor invasion and metastasis.

In 1998, in the study of transmembrane protein, Furuse found and identified a complete tight junction fragment in chicken liver for the first time, its relative molecular weight was 22,000 , and named it Claudin. ${ }^{34}$ So far, 27 members of the Claudins protein family have been found in humans, with a sequence identity of $12.5 \%-69.7 \%$, most of the relative molecular weight is 20,000-27,000. So far, 21 species have been identified to exist in the human body. ${ }^{35}$

Each molecular structure consists of four transmembrane domains and two extracellular annular domains. In the extracellular annular regions, the larger primary macrocycle is composed of 52 amino acid residues, while the secondary ring is composed of 16,033 residues. The same is that the terminal structures of amino and carboxyl groups are present in the cytoplasm, and there is a specific PDZ binding region on it. Among different Claudins protein molecules, the C-terminal sequence has different lengths of 210.63 residues, and the amino acid sequences of the first and fourth transmembrane fragments and the outer ring are highly conserved. These two annular structures of Claudins protein can contact the outside world through homologous or heterologous ways: (1) the longer extracellular ring mainly forms two different kinds of intercellular pores of paracellular open or closed, and these pores are the important structural basis for the formation of tight junctions, and pores play an important role in the formation of tight junction bands and ion-selective permeability. (1) the longer extracellular rings mainly form two different kinds of intercellular pores, which are open or closed, and these pores play an important role in the formation of tight junction bands and ion selective permeability. (2) the shorter extracellular loop is mainly responsible for the trans-binding between Claudins molecules and does not participate in the regulation of paracellular permeability, and the shorter extracellular loop is the binding site of enterotoxin from Cystitis perfringens, while the intracellular C-terminal is connected to tight junction protein (zonula occludens, ZO) molecules through different PDZ domains. ${ }^{36}$

The expression of Claudins protein is specific, and more than two kinds of Claudins protein molecules can be expressed in most tissues and organs. They are expressed not only in the tight junction but also on the side of some epithelial cells and on the basement membrane. It has been found that there are abnormal expressions of Claudin 1 and Claudin 4 in CRLM. Claudin1 can promote the activation of matrix metalloproteinase- 2 precursor and enhance the ability of invasion and metastasis of cancer cells. At the same time, the increased expression of Claudin1 can inhibit the expression of E-cadherin, Claudin 1 may be the target gene of $\beta$-catenin/Tcf ( $\mathrm{T}$ cell factor) signal pathway, the up-regulation of $\beta$-catenin/Tcf signal pathway can promote the occurrence and development of tumor, while the decreased expression of E-cadherin can promote the up-regulation of $\beta$-catenin /Tcf signal pathway, so the overexpression of Claudin 1 can promote tumorigenesis. ${ }^{37}$ Claudin 4 was previously low or non-expressed in colon cancer cells and highly expressed in cholangiocarcinoma. Recently, it has been found that Claudin4 is highly expressed in CRLM, but the specific mechanism remains to be studied.

\section{The Role of Oncogenes in Liver Metastasis of Colorectal Cancer}

Proto-oncogenes exist in the genomes of normal biological cells. Like tumor suppressor genes, proto-oncogenes play an important role in the regulation of cell growth and proliferation. Under normal circumstances, the ability is that the proto-oncogenes in the genome are in a state of low expression or non-expression, but when they encounter certain conditions, such as viral infection, chemical carcinogens or radiation, the proto-oncogenes will be abnormally activated and converted to oncogenes to induce cell carcinogenesis. In Table 2, we sorted out the abnormally expressed oncogenes found in the study of CRLM in recent years.

\section{$\mathrm{MACCl}$}

Metastasis-associated in colon cancer (MACC1) is closely related to liver metastasis of colorectal cancer. ${ }^{38}$ It was discovered and named by Stein using differential display RT-PCR technology in 2009. There is a small amount of 
Table 2 Non-Coding RNAs in Liver Metastasis of Colorectal Cancer

\begin{tabular}{|c|c|c|c|c|}
\hline Non-Coding RNAs & Expression & Major Effects & Targets & Reference \\
\hline NSUN2 (CircRNA) & $U_{p}$ & $\begin{array}{l}\text { Enhance the stability of HMGA2 mRNA by forming a circNSUN2/IGF2BP2/ } \\
\text { HMGA2 RNA-protein ternary complex }\end{array}$ & HMGA2 & [108] \\
\hline $000 I 178$ (CircRNA) & $U_{p}$ & - & - & {$[181]$} \\
\hline CSPPI (CircRNA) & $U_{p}$ & $\begin{array}{l}\text { Competitively binding to miR-193a-5p and preventing miR-193a-5p from } \\
\text { decreasing the expression of COLIAI }\end{array}$ & COLIAI & [182] \\
\hline 0000826 (CircRNA) & Up & - & - & [183] \\
\hline Circ-I33 (CircRNA) & Up & $\begin{array}{l}\text { Exosomal circ- } 133 \text { derived from hypoxic cells delivered into normoxic cells and } \\
\text { promoted cancer metastasis by acting on miR- } 133 \mathrm{a} / \mathrm{GEF}-\mathrm{HI} / \mathrm{RhoA} \text { axis }\end{array}$ & $\begin{array}{l}\text { GEF-HI } \\
\text { /RhoA }\end{array}$ & [103] \\
\hline 102049 (CircRNA) & Up & $\begin{array}{l}\text { Significantly enhanced the adhesion, migration and invasion abilities of CRC cells, } \\
\text { and promoted CRC progression via a miR-76I/miR-192-3p-FRASI-dependent } \\
\text { mechanism }\end{array}$ & FRASI & [184] \\
\hline CLMAT3 (IncRNA) & $U_{p}$ & - & - & {$[185]$} \\
\hline UICLM (IncRNA) & Up & Acted as a ceRNA for miR-215 to regulate ZEB2 expression & ZEB2 & [92] \\
\hline HOXAII-AS (IncRNA) & Up & Functioning as a miR-125a-5p sponge, promote the expression of PADI2 & PADI2 & {$[101]$} \\
\hline SNHG7 (IncRNA) & Up & Functioning as a miR-2I6B sponge, promote the expression of GALNTI & GALNTI & {$[186,187]$} \\
\hline CRNDE (InCRNA) & $U_{p}$ & - & - & [187] \\
\hline SNHGI5 (IncRNA) & $U_{p}$ & - & - & [188] \\
\hline RPII-757GI.5 (IncRNA) & Up & RPII-757GI.5 regulated the expression of YAPI through sponging miR-139-5p & YAPI & [189] \\
\hline B3GALT5-ASI (IncRNA) & Down & $\begin{array}{l}\text { Directly bound to the promoter of miRNA-203, repressed miR-203 expression, } \\
\text { upregulated miR-203 targets ZEB2 and SNAI2, and induced epithelial-to- } \\
\text { mesenchymal transition (EMT) }\end{array}$ & ZEB2, SNAI2 & [190] \\
\hline miR-I46a (miRNA) & Up & Impede c-met and NUMB translation & $\begin{array}{l}\text { c-met, } \\
\text { NUMB }\end{array}$ & {$[191,192]$} \\
\hline miR-17 (miRNA) & $U_{p}$ & - & - & [193] \\
\hline miR-487b (miRNA) & Down & $\begin{array}{l}\text { miR-487b directly targeted LRP6, a receptor for WNT/ } \beta \text {-catenin signaling and } \\
\text { suppress metastasis of CRC progression through inhibition of KRAS }\end{array}$ & LRP6, KRAS & [83] \\
\hline miR-320a (miRNA) & Down & $\begin{array}{l}\text { miR-320a directly binds to the } 3^{\prime} U T R \text { of neuropilin I (NRP-I), a protein that } \\
\text { functions as a co-receptor of vascular epithelial growth factor }\end{array}$ & NRP-I & [194] \\
\hline miR-I22 (miRNA) & $U_{p}$ & $\begin{array}{l}\text { Concomitant suppression of CATI in the primary tumor appears to play } \\
\text { important roles in the development of colorectal liver metastasis }\end{array}$ & CATI & [195-197] \\
\hline miR-340 (miRNA) & Down & Inhibite growth of colon cancer cells and suppressed c-Met expression & c-Met & [198] \\
\hline miR-200b (miRNA) & \multirow[t]{3}{*}{ Down } & \multirow[t]{3}{*}{-} & \multirow[t]{3}{*}{-} & \multirow[t]{3}{*}{ [199] } \\
\hline miR-200c (miRNA) & & & & \\
\hline miR-429 (miRNA) & & & & \\
\hline miR-I26 (miRNA) & \multirow{3}{*}{$\begin{array}{l}\text { Down } \\
\text { Up }\end{array}$} & \multirow[t]{3}{*}{-} & \multirow[t]{3}{*}{-} & \multirow[t]{3}{*}{ [200] } \\
\hline miR-I4I (miRNA) & & & & \\
\hline miR-2I (miRNA) & & & & \\
\hline miR-2l4 (miRNA) & Down & $\begin{array}{l}\text { FGFRI knockdown mimicked the tumor suppressive effect of miR-2I4 on CRC } \\
\text { cells, while reintroduction of FGFRI abolished the tumor suppressive effect of } \\
\text { miR-2I4 on CRC cells }\end{array}$ & FGFRI & [20I-203] \\
\hline
\end{tabular}

(Continued) 
Table 2 (Continued).

\begin{tabular}{|c|c|c|c|c|}
\hline Non-Coding RNAs & Expression & Major Effects & Targets & Reference \\
\hline miR-574-5p (miRNA) & Up & $\begin{array}{l}\text { Played a suppressive role in colorectal cancer liver metastasis by negatively } \\
\text { directing MACC-I expression }\end{array}$ & MACC-I & [204] \\
\hline miR-I8Ia (miRNA) & $U_{p}$ & $\begin{array}{l}\text { miR- }|8| \mathrm{I} \text { a has strong tumor-promoting effects through inhibiting the expression } \\
\text { of WIF-I, and its potential role in promoting epithelial-mesenchymal transition }\end{array}$ & WIF-I & [205] \\
\hline miR-99b-5p (miRNA) & $U_{p}$ & $\begin{array}{l}\text { miR-99b-5p silencing in miR-99b-5p-positive CRC cell lines promoted cell } \\
\text { migration and up-regulated mTOR }\end{array}$ & mTOR & [206] \\
\hline miR-138 (miRNA) & Down & $\begin{array}{l}\text { Downregulation of miR-138 as a Contributing Mechanism to Lcn-2 } \\
\text { Overexpression in Colorectal Cancer with Liver Metastasis }\end{array}$ & Len-2 & [207] \\
\hline miR-IOb (miRNA) & $U_{p}$ & - & - & [208] \\
\hline miR-203 (miRNA) & Up & - & - & [209] \\
\hline miR-198 (miRNA) & Down & Tenascin $C$ as a predicted target of miR-198 that promote liver metastasis & Tenascin C & {$[210]$} \\
\hline miR-125a-5p (miRNA) & Down & $\begin{array}{l}\text { Participate in liver Metastasis of Colorectal Cancer through miR-125a-5p-PADI2 } \\
\text { Regulatory Network }\end{array}$ & PADI2 & {$[101]$} \\
\hline miR-200s (miRNA) & $U_{p}$ & $\begin{array}{l}\text { PKC } / \text { /ADAR2 axis is a critical regulator of CRC metastases through modulation } \\
\text { of miR-200 levels }\end{array}$ & $\begin{array}{l}\text { PKCל/ } \\
\text { ADAR2 }\end{array}$ & [82] \\
\hline miR-20a (miRNA) & \multirow[t]{2}{*}{$U_{p}$} & \multirow[t]{2}{*}{-} & \multirow[t]{2}{*}{-} & \multirow[t]{2}{*}[211]{} \\
\hline miR-576-5p (miRNA) & & & & \\
\hline miR-143-3p (miRNA) & \multirow[t]{4}{*}{ Down } & \multirow[t]{4}{*}{-} & \multirow[t]{4}{*}{-} & \multirow[t]{11}{*}[212]{} \\
\hline miR-10b-5p (miRNA) & & & & \\
\hline miR-2I-5p (miRNA) & & & & \\
\hline miR-5I8f-5p (miRNA) & & & & \\
\hline miR-122-5p (miRNA) & \multirow[t]{7}{*}{$U_{p}$} & \multirow[t]{7}{*}{-} & \multirow[t]{7}{*}{-} & \\
\hline miR-885-5p (miRNA) & & & & \\
\hline miR-210-3p (miRNA) & & & & \\
\hline miR-130b-5p (miRNA) & & & & \\
\hline miR-I275 (miRNA) & & & & \\
\hline miR-139-3p (miRNA) & & & & \\
\hline miR-I290 (miRNA) & & & & \\
\hline miR-132 (miRNA) & \multirow[t]{4}{*}{ Down } & \multirow[t]{4}{*}{-} & \multirow[t]{4}{*}{-} & \multirow[t]{4}{*}{ [2।3] } \\
\hline miR-378f (miRNA) & & & & \\
\hline miR-605 (miRNA) & & & & \\
\hline miR-1976 (miRNA) & & & & \\
\hline miR-25-3p (miRNA) & \multirow[t]{3}{*}{$U_{p}$} & \multirow{3}{*}{$\begin{array}{l}\text { M2 polarized macrophages promoted cancer metastasis by enhancing epithelial- } \\
\text { mesenchymal transition and secreting vascular endothelial growth factor (VEGF) }\end{array}$} & \multirow[t]{3}{*}{ VEGF } & \multirow[t]{3}{*}{ [2।4] } \\
\hline miR-130b-3p (miRNA) & & & & \\
\hline miR-425-5p (miRNA) & & & & \\
\hline
\end{tabular}


Table 2 (Continued).

\begin{tabular}{|c|c|c|c|c|}
\hline Non-Coding RNAs & Expression & Major Effects & Targets & Reference \\
\hline miR-139-5p (miRNA) & Down & $\begin{array}{l}\text { LncRNA RPI I-757GI.5 regulated the expression of YAPI through sponging } \\
\text { miR-I39-5p and inhibiting its activity thereby promoting CRC progression and } \\
\text { development }\end{array}$ & YAPI & {$[189,2 \mid 2]$} \\
\hline miR-493 (miRNA) & Down & $\begin{array}{l}\text { Inhibit the expression of MKK7 by targeting the 3-UTR binding site of MKK7 } \\
\text { gene and promotes liver metastasis of colon cancer cells }\end{array}$ & $\begin{array}{l}\text { IGFIR } \\
\text { MKK7 }\end{array}$ & [215] \\
\hline miR-192 (miRNA) & Down & $\begin{array}{l}\text { Downregulate expression of Bcl-2, Zeb2 and VEGFA in vitro and in vivo, which is } \\
\text { responsible for enhanced apoptosis, increased expression of E-cadherin and } \\
\text { decreased angiogenesis in vivo }\end{array}$ & $\begin{array}{l}\text { Bcl-2, Zeb2, } \\
\text { VEGFA }\end{array}$ & [216] \\
\hline miR-934 (miRNA) & $U_{p}$ & $\begin{array}{l}\text { Induce the polarization of M2 macrophages by down-regulating the expression of } \\
\text { PTEN and activating PI3K/AKT signaling pathway, and induces the formation of } \\
\text { pre-metastatic niche and promotes the formation of CRLM by secreting } \\
\text { CXCLI3 }\end{array}$ & PTEN & [2।7] \\
\hline miR-2I5-5p (miRNA) & Down & $\begin{array}{l}\text { Low expression of miR-215-5p can reverse the overexpression of CTNNBIPI } \\
\text { and promote distant metastasis. }\end{array}$ & CTNNBIPI & [2।8] \\
\hline
\end{tabular}

MACC1 expression in normal tissues and abnormally high expression in many kinds of malignant tumors, but the expression level is the highest in colon cancer cells. Studies have also shown that the increase of MACC1 expression is often accompanied by the occurrence of malignant tumors, and the 5-year survival rate of patients with high expression of MACC1 mRNA is significantly lower, and the risk of death is increased. ${ }^{39}$ MACC1 has a strong correlation with the clinicopathological features, development and prognosis of the tumor, and can be used as an independent evaluation index of metastasis and prognosis.

The MACC1 gene is located on human chromosome 7 (7p21. 1), there are about 76,762 base pairs, including 7 exons and 6 introns. Its cDNA has a sequence of 2559 nucleotides and encodes a protein of 852 amino acids. MACC1 protein is a protein complex composed of multiple domains, including ZU5, SH3 and two C-terminal death domains (death domain, DD). It has been found that transfection of MACC1 containing SH3 domain and proline-rich sequence into colon cancer cell lines that do not express MACC1 can enhance cell viability and proliferation, while MACC1 mutants without this domain lack these abilities, indicating that SH3 domain and SH3 binding motif are essential to maintain the biological function of MACC1.

HGF is a multiple growth factor, which is a growth stimulating factor secreted by hepatocytes and endothelial cells. ${ }^{40}$ MET protein is encoded by proto-oncogene c-met and is the membrane-specific receptor of HGF. ${ }^{41}$ HGF can bind to specific MET receptors through autocrine, paracrine and classical axonal reverse transport. The combination of the two can activate HGF/MET signal pathway, cause cell proliferation, mucosal epithelial transformation, promote angiogenesis, enhance cell movement, enhance tumor cell invasion and metastasis and so on. ${ }^{42}$ MACC1 is a key gene regulating HGF/MET pathway. It has been found that the expression of MACC1 mRNA and MET RNA is high or low in gastrointestinal tumors. As a transcription factor, MACC1 can bind to MET promoter and enhance the expression of MET. ${ }^{43}$ MACC1 siRNA can inhibit cell proliferation and movement, reduce metastasis in vivo, and greatly reduce the expression of MET RNA and its protein.

It has been found that the abnormal expression of MACC1 gene plays an important role in CRLM. Stein $\mathrm{U}$ experiments have confirmed that MACC1 has the ability to induce cell migration, infiltration and proliferation. They found similar results in vitro and in vivo animal experiments on SW480 cell line from primary focus of colon cancer and liver metastatic cell line SW620 from the same specimen. All these fully show that MACC1 has important research significance in colorectal liver metastasis. It can not only be used as a marker for early diagnosis but also guide clinical treatment and even drug research and development.

\section{SNCG}

$\gamma$-synaptophysin (SNCG) is a member of the neuronuclear protein family, which is located on chromosome 10q23. 2-q23.3. The transcriptional product mRNA is about 
$100 \mathrm{bp}$, long and encodes a protein of less than 123 amino acid. $^{44} \mathrm{Ji}$ isolated human breast cancer cDNA library by differential cDNA sequence in $1997 .{ }^{45}$ Because of its high expression in advanced breast cancer, it was once called breast cancer-specific gene (BCSGI). However, recent studies have shown that SNCG is highly expressed in many organ tumors, especially in advanced malignant tumors, including breast cancer, ovarian cancer, pancreatic cancer, colorectal cancer and so on. It is almost undetectable or low expression in adjacent non-tumor tissues and is related to tumor invasion and metastasis.

Synaptophysin is a small molecular soluble protein family mainly expressed in nerve tissue, which is distributed among different species and genera, and contains 127-140 amino acid homologous sequences that are highly conserved in the process of evolution. SNCG is located on chromosome 10q23 and is about $5 \mathrm{~kb}$ in length. It consists of five exons and is transcribed into a mRNA, polypeptide encoding $127 \mathrm{AA}$ of $1 \mathrm{~kb}$. The results of the SNCG sequence obtained from BAC clone 174P13 and the reported expression sequence tag (expressed sequence tags, ESTs) showed that there were four single nucleotide polymorphism (SNP) sites in the SNCG gene: the upstream-19 site of AUG, the 3 'untranslated region of AUG, the 122bp behind the stop codon UAG, and the third base of the 65th codon. In particular, the change of GTG glutamate GAG in exon 4 leads to the change of amino acid: valine (Val) 110 glutamate (Glu).

A great deal of evidence shows that the abnormal expression of SNCG protein in tumor cells is not due to gene mutation and amplification, but to the activation of transcription. ${ }^{46,47}$ There are four main factors that affect the transcription and expression of SNCG: (1) Activator protein 1 (AP1) can activate the AP1 site in the AP1,TPA binding intron through AP1 activators such as TPA to upregulate the activity of the promoter and increase the expression of SNCG mRNA. ${ }^{48-50}$ (2) BubR1 is the main component of the cell division checkpoint, which can monitor the correct assembly of mitotic spindles, so as to ensure the correct separation of homologous chromosomes and prevent cells from escaping the checkpoint to make homologous chromosomes nonsynaptic. SNCG can inhibit the effect of BubR1 by binding to BubR1-microtubulin E (CENP-E) complex, which makes cells escape the control of mitotic checkpoints and form aneuploidy of chromosomes, thus increasing genetic instability and inducing tumorigenesis. ${ }^{51}$ (3) $\mathrm{CpG}$ island demethylation of SNCG can activate SNCG expression, which is to some extent consistent with the activation and expression mechanism of proto-oncogenes and growth-related factors in tissue cells. $^{52}$ (4) SNCG can promote cell proliferation and inhibit the control of mitotic checkpoints by activating estrogen receptors, leading to tumorigenesis and progression. ${ }^{53}$

The latest study has found that there is a significant high expression of SNCG in CRLM. ${ }^{54}$ The 5 -year survival rate and prognosis of patients with colorectal liver metastasis with SNCG positive are significantly lower than those with SNCG negative, indicating that the expression of SNCG can be used as an independent prognostic factor for colorectal cancer liver metastasis and can be used as an index for early diagnosis or to guide the next step of treatment.

\section{Chemokine and Its Receptor}

Chemokines are the largest known superfamily of cytokines, and more than 50 kinds of chemokine and more than 20 kinds of chemokine receptors have been found so far. ${ }^{55}$ By binding to receptors, chemokines participate in neovascularization, ${ }^{56}$ further affect tumor formation and metastasis, ${ }^{57}$ and play an important role in liver metastasis of colorectal cancer.

Chemokine is a small molecular cytokine with molecular weight of 8000-12,000, which has chemotactic effect on many kinds of cells, such as neutrophils, lymphocytes, monocytes and so on. According to the position of the conserved sequence of terminal hemisteminic acid, they can be divided into four categories: $\mathrm{CXC}, \mathrm{CC}$, and $\mathrm{CX} 3 \mathrm{C}$. Chemokines play a role by binding to the corresponding G-protein-coupled receptor superfamily. Chemokines affect tumor in many ways: some chemokines can inhibit tumor growth and development by activating immunoreactive cells or inhibiting tumor-related angiogenesis; other chemokines promote tumor development by enhancing tumor cell proliferation and migration, proteolytic enzyme secretion and inducing tumor angiogenesis, which show that chemokine network involved in tumor formation and metastasis is complex. ${ }^{58}$

There are four steps for cells to overcome vascular endothelial cell barrier between body fluid and tissue: cells flow with body fluid, cells are firmly attached to vascular endothelium, cells pass through endothelial intercellular space, and cells migrate to specific tissues. In this process, chemokines control the selection of exudative cells and the stable adhesion of the selected cells. The migration, invasion and metastasis of tumor cells are affected by chemokines and their receptors. It has been 
confirmed that chemokines regulate the metastasis of tumor cells and determine the target tissue of tumor metastasis. The interaction between chemokines specifically expressed in the target organs of tumor metastasis and the corresponding receptors expressed by the tumor can cause the polymerization of intracellular actin and regulate the movement and migration of cells. Therefore, the specific metastasis of tumor cells is closely related to the chemokine receptors expressed by tumor cells and the chemokines expressed by target organs.

There are also many chemokines involved in CRLM. There are also many chemokines involved in CRLM. CXCR4 is a chemokine receptor that plays an important role in CRLM and has a significantly high expression in CRLM, indicating that mediating tumor metastasis can become an important marker for the diagnosis of liver metastasis. The basic steps of the effect of CXCR4 on cancer cell metastasis may be: (1) cloning and expansion of cancer cells, infiltration of local tissue, angiogenesis, and expression of CXCR4; on the surface of tumor cells. (2) the cancer cells fall off from the primary tumor, pass through the lymphatic and vascular walls in the tumor, and enter the systemic circulation. (3) CXCR4 can make cancer cells invade normal tissue through CXCR4/TGF- $\beta 1$ axis, cell expansion and angiogenesis, which leads to liver metastasis. ${ }^{59}$ CXCL8 and its receptor CXCR1, CXCR2 can induce epithelial-mesenchymal transformation (EMT), of colorectal cancer cells to help them escape from host immune surveillance and enhance their resistance to anestrous apoptosis, thus promoting the formation of circulating tumor cells (CTCs) and their colonization in distant organs. ${ }^{60}$

With the further research, it has been found that chemokines and their receptors play a role in promoting distant metastasis in CRLM, but the mechanisms of a small number of chemokines have been declassified, but the mechanisms of most of the chemokines that have been found in CRLM cells are still unclear, which need to be further explored and expected to be transformed into early diagnostic indicators or drugs.

\section{Brief Overview of Non-Coding RNAs}

Over the past 10 years, with the development of next generation sequencing and bioinformatics, there has been a great variety. Thousands of Non-coding RNA has been discovered. $^{19,20}$ MiRNA $^{61-63}$ and piRNA ${ }^{64,65}$ were first discovered as a kind of small RNA. Then it was discovered that IncRNA. With the increase of species evolution, the number of small RNAs (especially miRNA) and lncRNA gradually increased. In recent years, it has been found that there are a large number of non-coding RNA, namely circRNA, in eukaryotic multicellular organisms. ${ }^{66-68}$ With the in-depth study of ncRNA, it has been found that ncRNA can participate in the occurrence and development of tumors through a variety of mechanisms. We summarized the role of ncRNA in liver metastasis of colorectal cancer. In Table 2, we summarize the progress in the field of non-coding RNAs research in recent years.

\section{The Role of miRNAs in Liver Metastasis of Colorectal Cancer}

MiRNA is a class of highly conserved, 18-25 nucleotides long endogenous single-stranded non-coding small molecule RNA. ${ }^{69}$ MiRNA exists widely in eukaryotes, and it does not have an open reading frame and does not encode proteins, but miRNA has the characteristics of clustering and can be coexpressed with related genes. ${ }^{70}$ In tumors, miRNA usually plays the role of tumor genes or tumor suppressor genes in the occurrence and development of tumors. ${ }^{71}$ Onco-miRNA such as miR-21 and miR-10b have oncogene-like functions and are positively correlated with tumorigenesis. Their overexpression or continuous activation will directly lead to tumorigenesis and development. ${ }^{72,73}$ Suppressor-miRNA such as miR-15/16 and Let-7 have the function similar to tumor suppressor gene. It has a negative correlation with tumorigenesis, and its down-regulation or inactivation will directly lead to tumorigenesis and development. ${ }^{74,75}$

MiRNA participates in tumorigenesis, development and metastasis in many ways. Drosha and Dicer are members of the RNase III family, mediating the splicing of the doublestranded complex from primiRNA to pre-miRNA and from pre-miRNA to miRNA, respectively. Many studies have shown that the expression and activity of Drosha and Dicer participate in the occurrence and development of tumor by affecting the synthesis of mature miRNA. ${ }^{76,77}$ Some scholars have proposed the "ceRNA hypothesis", that is, ceRNA (competing endogenous RNA) can compete with the MRE elements of the 3 '-UTR region of tumor genes, tumor suppressor genes and tumor-related signaling pathways to combine with miRNA, antagonize or regulate the function of tumor suppressor or tumorigenic miRNA, so it plays an important role in tumorigenesis, development, invasion, metastasis and drug efficacy. ${ }^{78}$ 


\section{The Main Mechanism of miRNAs Regulation in CRLM}

In the cells of colorectal cancer liver metastasis (CRLM), researchers found a variety of abnormal expression of miRNA, indicating that miRNA is closely related to colorectal liver metastasis. Among them, epithelial-mesenchymal transition (EMT) is the main mechanism, and most miRNA can directly or indirectly affect EMT to promote the occurrence of liver metastasis. EMT specifically refers to the transformation of cell phenotypes between epithelium and mesenchyme, which was first discovered in the process of embryonic development. In recent years, researchers have gradually paid more and more attention to its role in tumorigenesis and other diseases. ${ }^{79,80}$ EMT makes epithelial cells remove differentiated phenotypes, including cell-cell adhesion, top-bottom polarity, low motor ability, and obtain the phenotypes of some mesenchymal cells, including migration, invasion, anti-apoptosis and so on. ${ }^{81}$ MiRNAs can regulate EMT through a variety of gene loci in the process of liver metastasis of colorectal cancer. The miRNA-200 family is the hub for the regulation of EMT found by the latest research, which mainly includes miR-200a, miR-200b, miR-200c, miR-200s, miR-141, miR-429 and so on. The study of Shelton Pm found that the expression of miR-200s was significantly increased in CRLM. It promotes metastasis and regulates EMT through the PKC ל/ADAR2 axis. ${ }^{82}$ KRAS is an important targeted tumor suppressor gene. In tumors, the miRNAs, cascade of some targeted oncogenes KRAS activates KRAS, activated RAS response original binding protein (RREB1), which directly inhibits the transcription of miRNA clusters including miR-384, miR-487b and down-regulates the expression of KRAS in subcutaneous or xenotransplanted tumors by transcriptional up-regulation of these miRNA or liposome delivery systems. ${ }^{83}$ At the same time, a variety of miRNAs can pass through various signals such as mTOR, PTEN, PKC $/$ ADAR2, etc, affect the proliferation of blood vessels around the tumor, reduce tumor cell adhesion, and promote the progress of CRLM.

Thus, many miRNAs have been found in CRLM, and the related mechanisms of their regulation of CRLM are gradually becoming clear. It is believed that miRNA will play an important role in the diagnosis and treatment of CRLM.

\section{The Role of IncRNAs in Liver Metastasis of Colorectal Cancer}

In 2002, Japanese researchers first put forward the concept of lncRNA, which refers to non-coding RNA with a length of more than 200 nt. $^{84}$ Until 2007, a highly expressed functional lncRNA gene of $2.2 \mathrm{~kb}$ was found for the first time in breast cancer, proving the role of lncRNA in tumorigenesis and development. ${ }^{85}$

LncRNA has a 5'- cap structure and a 3'- terminal polyadenylate tail, and its gene structure is similar to that of mRNA. ${ }^{86}$ LncRNA can act as the sponge of microRNA and adsorb some specific microRNA, in the way of bait so as to regulate the expression of some microRNA target genes. The lncRNA with this function is also known as ceRNA (Competing endogenous RNA). ${ }^{87}$ At the same time, because the expression of most long non-coding genes is transcribed by RNA polymerase II (RNAP II), the specific expression of these genes in tissues and developmental stages indicates that the transcription of these genes is strictly regulated, so people can infer the state of chromatin according to the expression of IncRNA. In addition, IncRNA can also regulate tumor suppression or oncogene expression. Many studies have shown that lncRNA has a variety of other effect mechanisms, it can be used as signal molecules, bait molecules and guiding, functional scaffolds, but also can interact with other biomolecules to form a certain module structure to exert its biological function. ${ }^{88,89}$ It can be seen that LncRNA is closely related to the occurrence and development of tumors. ${ }^{90}$

\section{The Main Mechanism of IncRNAs Regulation in CRLM}

ZEB2 can directly down-regulate the expression of cell junction-related genes, including adhesive junctions, tight junctions, desmosomes and gap junctions. ZWB2 can increase the expression of interstitial proteins (such as vimentin and $\mathrm{N}$-cadherin), which is common in the cell cord of hepatocellular carcinoma. ${ }^{91}$ The study of Chen Dl found that the expression of lncRNA-UICLM in CRLM was significantly increased, while the expression of tumor suppressor gene ZEB2 was significantly decreased. Further study of the mechanism found that IncRNA-UICLM is a competitive endogenous RNA, of miR-215, that is, IncRNA-UICLM can be used as a "sponge" of miR-215, that is, it absorbs miR-215, to inhibit the expression of ZEB2 and accelerate the occurrence of liver metastasis of colorectal cancer. ${ }^{92}$

PDI2 (Peptidyl arginine deiminase 2) was first confirmed in animal experiments to have a high expression in HER2/ ERBB2 (+) breast cancer, and when PDI2 is inhibited, the tumor cells will be significantly suppressed. Several recent studies have reported that PDI2 is involved in tumorigenesis and plays an important role in the development of many 
malignant tumors such as spontaneous skin tumors, multiple myeloma, breast cancer and colorectal cancer. ${ }^{93-95}$ MiR$125 \mathrm{a}-5 \mathrm{p}$ is a classic tumor suppressor gene. At present, many studies at home and abroad have found that it can effectively inhibit the invasion and metastasis of common tumors, including hepatocellular carcinoma, gastric cancer, breast cancer, lung cancer, glioma, melanoma and so on. The regulatory targets of its inhibitory effect in different tumors are SIRT7, PI3K, E2F3, ERBB2, TSTA3, HDAC4, HDAC5, EGFR, Gab2, Lin28B and other genes. ${ }^{96-100}$ Chen et al found that IncRNA HOXA11-AS can act as a "sponge" of miR$125 \mathrm{a}-5 \mathrm{p}$, promoting the expression of PADI2, which leads to liver metastasis of colorectal cancer. ${ }^{101}$

LncRNA can affect the occurrence and development of CRLM through a variety of mechanisms, but it is still necessary to further explore the different mechanisms and pathways of different IncRNA, which is very important for the early diagnosis and even treatment of CRLM in the future.

\section{The Role of circRNAs in Liver Metastasis of Colorectal Cancer}

The role and mechanism of circRNA in tumor is one of the recent research hotspots. In 2013, Jeck detected more than 25,000 circRNAs in human fibroblasts. ${ }^{68}$ They realized that circRNA is widespread in the human body and may play an important role in the spectrum of human diseases. CircRNA is a special type of endogenous non-coding RNA whose 3 'end and 5'end are connected to form a closed covalent ring structure. This structure makes circRNA more stable and highly conserved. Since circRNA has one or more miRNA binding sites, it can reduce the activity of miRNA by binding to miRNA, weaken the inhibitory effect of miRNA on target genes, thereby regulating the expression of related target genes, and ultimately leading to increased production of messenger RNA. The biological effect is strengthened, this is the competitive-binding mechanism, and this effect is called "miRNA sponge". At the same time, circRNA can combine with specific proteins to form RNA-protein complexes, thereby affecting protein translation and regulating protein functions.

\section{The Main Mechanism of circRNAs Regulation in CRLM}

In CRLM, most of the circRNA found at present acts as the "sponge" of miRNA to play its role. GRF-H1 is a kind of regulatory protein that regulates the activity of Rho GTP by regulating its GDP/GTP exchange. As an important regulator, it plays an important role in the biological process of mammals, especially in the proliferation and migration of tumor cells. ${ }^{102}$ The study of Yang $\mathrm{H}$ found that circ-133 can up-regulate the expression of RhoA by competitively binding to miR-133a in colorectal cancer cells; the overexpression of RhoA can reverse the inhibitory effect of circ-133 on the progression of colorectal cancer, indicating that circ-133 can promote the progression of colorectal cancer through the miR-133a/GEF-H1/RhoA axis. ${ }^{103}$

The HMGA2 gene is located in $12 \mathrm{q} 13-15$. There are 5 exons in $200 \mathrm{~Kb}$, and each exon is independently encoded by HMGA2 gene. ${ }^{104}$ In normal human tissues, HMGA2 encodes a complete protein product with a relative molecular weight of 12,000. The protein is mainly located in the nucleus and belongs to non-histone chromosome protein. ${ }^{105}$ Widely expressed in eukaryotes, it does not have the ability of direct transcriptional regulation, but it can bind to the AT enrichment region of the regulated gene DNA through the unique AT hook structure, causing DNA to bend, stretch, ring or unchain, thus changing the structure of chromatin and enhancing its transcriptional activity, also known as structural transcription factors. ${ }^{106}$ Transcripts of HMGA2 gene can hardly be detected in normal adult tissues. In recent years, studies have shown that HMGA2 is abnormally expressed in a variety of cancer tissues, and participates in the regulation of a variety of biological behaviors, and plays a role in promoting the occurrence and development of cancer. The degree of expression is closely related to the clinicopathological features and the survival and prognosis of patients. ${ }^{107}$ Chen RX's study found that CircNSUN2 and HMGA2 were highly expressed in colorectal liver metastatic cancer cells. Further studies showed that N6methyladenosine modification of CircNSUN2 increased cytoplasmic output, thus through the formation of CircNSUN2/ IGF2BP2/HMGA2RNA-protein ternary complex in the cytoplasm to enhance the stability of HMGA2 mRNA and promote colorectal cancer metastasis. ${ }^{108}$

According to the current research, there are still few studies on CRLM in circRNA, but it has been found that circRNA can affect the liver metastasis of colorectal cancer through different mechanisms. For example, as a sponge of miRNA, or regulating the expression of coding genes, it is proved that circRNA plays an important role in the occurrence of CRLM, which points out the direction for further research.

\section{Clinical Treatment of Liver Metastasis of Colorectal Cancer}

The liver is one of the most common organs with distant metastasis of colorectal cancer. Correct and effective 
treatment of liver metastasis can not only delay the progress of the disease and prolong the life span of patients but also provide a good guarantee for the quality of prognosis of patients. At present, surgical resection is still the first choice for liver metastasis of colorectal cancer. With the continuous development of related technologies and the in-depth study of liver metastasis of colorectal cancer, new treatment methods such as radiotherapy, cryotherapy and radiofrequency ablation are also being put into practice. Multidisciplinary comprehensive treatment will provide a new research direction for the clinical treatment of liver metastasis of colorectal cancer.

\section{Surgical Resection}

Surgical resection is the first choice for the treatment of liver metastasis of colorectal cancer at present. Standardized surgical treatment is generally advocated for CRC patients with surgical indications. ${ }^{109}$ The progress of medicine is changing with each passing day. With the improvement of surgery and multidisciplinary comprehensive treatment, the concept of resectability of liver metastatic cancer is constantly updated. The latest concept of surgical resection is: (1) all metastatic lesions of the liver can be removed; (2) the residual liver volume after resection is more than $30 \%$ of the original volume; and (3) extrahepatic metastatic lesions can be removed. At present, experts agree that as long as the residual liver can be compensated, the scope of resection should be expanded as far as possible, so that $20 \%$ of patients have the opportunity to operate. ${ }^{110}$

If the primary focus of colorectal cancer is found to have liver metastasis at the same time, or if liver metastasis occurs within 6 months after radical operation, it is called synchronous liver metastasis; if the primary focus is cured for more than 6 months, the recurrent liver metastasis is called metachronous liver metastasis. For patients with simultaneous liver metastasis, surgeons still have difficulties in the choice of simultaneous resection or staging resection. Simultaneous resection avoids the pain of the second operation and correspondingly reduces the incidence of postoperative complications. The survival benefit of staging resection depends on the biological behavior of the tumor, but the operative complications and mortality are higher, but it can make the occult liver metastasis more obvious and reduce the postoperative recurrence rate of simultaneous resection. ${ }^{109}$

To sum up, surgical resection is still the first choice at present, but the formulation of treatment plan needs to be based on the actual situation of patients, according to multi-disciplinary comprehensive evaluation, and have a real-time understanding of the status of liver metastasis of patients.

\section{Radiofrequency Ablation Therapy}

Radiofrequency ablation is to make the electrode needle directly contact the metastatic tumor tissue under the guidance of ultrasound, CT and laparoscopy, connect the radio frequency current to the electrode needle, and produce heat through the ion shock produced by the current around the electrode needle, so as to achieve the therapeutic purpose of promoting coagulative necrosis of tumor tissue around the electrode needle. ${ }^{111}$ In general, the heat production temperature of the target area of radiofrequency ablation electrode needle can be as high as $100{ }^{\circ} \mathrm{C}$, which can cause irreversible thermal coagulation and necrosis of local tissue proteins, apoptosis and microcirculatory vascular embolism in surrounding tissues, inhibit the formation of blood vessels around the tumor, and prevent the blood dissemination of tumor cells, which has a definite effect on the treatment of liver metastatic lesions of colorectal cancer. ${ }^{112,113}$

The size of liver metastases, the number of liver metastases and the presence or absence of extrahepatic metastasis in patients with colorectal cancer are significantly related to the prognosis, efficacy and survival rate. Studies have shown that patients with liver metastases less than $3 \mathrm{~cm}$ in diameter, less than three and without extrahepatic metastasis can be treated with radiofrequency ablation with good accuracy, high repeatability, greater benefit and good prognosis. Most of the patients with liver metastasis of colorectal cancer who can not be operated are due to the lack of liver reserve and complications. In view of this situation, radiofrequency ablation can be used.

\section{Chemotherapy}

As a patient with unresectable colon cancer with liver metastasis, systemic chemotherapy can effectively prolong the survival time. According to the relevant information, the use of oxaliplatin combined with calcium folinate and fluorouracil has achieved considerable results. Using this kind of chemotherapy and continuing to maintain chemotherapy can increase the mPFS of patients with liver metastasis of colorectal cancer (median progression-free survival). However, this kind of method has severe adverse reactions to its own body, which seriously 
damages the life and health of patients. However, due to the frequency of chemotherapy, patients with liver metastasis of colorectal cancer are not as tolerant as they used to be.

\section{Targeted Therapy}

The application of molecular targeted therapy strategy to patients with liver metastasis of colorectal cancer also has a certain effect on the improvement of survival time of patients. At present, the selected molecular targeting drugs are mostly used for epidermal growth factor receptor or vascular endothelial growth factor receptor, and the common drugs are panizumab, bevacizumab, cetuximab and so on. Among them, panizumab and cetuximab are mostly used as epidermal growth factor receptor inhibitors, but after more in-depth studies, it is found that the applicable range of the population is gradually shrinking. In addition, cetuximab can be used as a first-line regimen in patients with liver metastasis of colorectal cancer. The obvious effect is the improvement of PFS and OS as well as the efficiency, but it is worth mentioning that if the opposite is a patient with BRAF gene mutation, the effect is very poor. In addition, when bevacizumab and cetuximab were used in patients with liver metastasis of colorectal cancer, the objective effective rate of bevacizumab and cetuximab was not significant. Therefore, in the selection of the above molecular targeted drugs, it is effective for patients with liver metastasis of colorectal cancer, but for patients to have a clear understanding of KRIS, BRAF gene status.

In the selection of molecular targeting drugs mentioned above, it is effective for patients with liver metastasis of colorectal cancer, but it is necessary to have a clear understanding of KRIS and BRAF gene status in patients. As for vascular endothelial growth factor inhibitor, it has not been found that gene status can affect receptor inhibitors. As a result, bevacizumab, which is led by bevacizumab, has gradually become a more respected treatment.

\section{Immunotherapy}

Tumor microenvironment (TME) is a local growth environment composed of tumor cells, tumor stem cells and surrounding infiltrating mesenchymal cells, immune cells, extracellular matrix, interstitial tissue near tumor cells, microvessels, and cytokines. ${ }^{114}$ It can be divided into a microenvironment dominated by immune cells and a non-immune microenvironment dominated by fibroblasts. ${ }^{115}$ When the tumor cells break through the immune defense line, the immune cells play an antitumor effect at the beginning of tumor invasion, but they also show the role of assisting tumor immune escape and distant metastasis during tumor progression. Immune cell infiltration can secrete inflammatory mediators, creating an inflammatory environment with a high degree of specificity. ${ }^{116}$ A variety of immune cells can mediate immune suppression and promote tumor progression in the tumor microenvironment.

With the continuous study of tumor immune mechanisms, immunotherapy has made major breakthroughs in the treatment of malignant tumors. Immunotherapy drugs have achieved many results in clinical trials, and some immunotherapy drugs have been approved for marketing. For CRLM patients, a variety of immunotherapy options can significantly prolong survival, such as tumor vaccines, immunosuppressive agents, and small molecule therapy.

Tumor vaccine therapy uses tumor antigen genes and antigen peptide vaccines to improve the activity of the immune system, and induces the body to produce humoral immunity and cellular immunity through tumor antigen substances and tumor cells to enhance the ability of anticancer. Autologous transplantation of dendritic cells (DC) is a classic method of tumor vaccination. DCs can be modified to present tumor antigens and stimulate the adaptive immune system. ${ }^{117} \mathrm{DC}$ is a powerful TAA presenting cell with MHC (major histocompatibility complex)-I and MHC-II, which activates T cell immunity, has good safety for the treatment of advanced malignant tumors, and can prolong the survival period of CRLM patients.

Cellular immunotherapy refers to the separation of tumor-infiltrating lymphocytes, natural killer cells and other lymphocytes from tumor tissues and blood, which are transformed, activated, expanded and then re-infused into the body to achieve the killing effect on tumor cells. Cellular immunotherapy includes cytotoxic $\mathrm{T}$ cell therapy (CTL), genetically modified T cell receptor therapy (TCR$\mathrm{T})$, lymphokine activated killer cell therapy (LAK) and other treatment options. ${ }^{118}$ A recent study showed that cellular immunotherapy combined with oxaliplatin, fluorouracil, and folic acid combined with chemotherapy can appropriately prolong the overall survival and progressionfree survival of patients with metastatic colon cancer. ${ }^{119}$ TCR-T is a type of cellular immunotherapy. The treatment process is to chimerize tumor-specific antigen receptors into $\mathrm{T}$ cells, and then genetically modify $\mathrm{T}$ cells back into the body to stimulate $\mathrm{T}$ cells to specifically recognize and kill tumor cells. Katz SC's research confirmed that the 
percutaneous hepatic artery injection method can significantly reduce the CEA level in patients with liver metastases. $^{120}$

Immunosuppressant therapy is one of the current research hotspots. The target of this treatment is the activation and inhibitory receptors distributed on the surface of $\mathrm{T}$ lymphocytes. The activated receptors include CD28, GITR, CD27, etc, and the inhibitory receptors include programmed death 1 (PD-1), cytotoxic T-lymphocyte antigen-4 (CTLA-4), etc. These receptors are also called immune checkpoints. PD-1 is expressed on the surface of immune cells, and programmed cell death ligand 1 (PD-L1) is a tumor cell surface ligand. The surface of solid tumor invading lymphocytes shows PD-1 positive, and PD-1 binds to PD-L1 Inhibit the function of T lymphocytes and induce immune escape of tumor cells. Therefore, blocking PD-1 binding to PD-L1 can reduce tumor cell immune escape. $^{121}$ Immunosuppressants against PD-1/PD-L1 that have been marketed include nivolumab, pembrolizumab, and atezolizumab. Relevant studies have shown that immunosuppressive therapy can significantly prolong the median progression-free survival of patients and the advantage of progression-free survival is more prominent. ${ }^{122}$ The reason may be that chemotherapy drugs have a fast onset of cytotoxicity, and PD-1 inhibitors are induced by regulating the immune microenvironment. T cells kill tumor cells, and checkpoint inhibitors work slower than chemotherapy drugs. $^{123}$

Immunotherapy has become a hot spot in current tumor treatment research, and obvious curative effects can also be seen in CRLM. However, there are still some problems: on the one hand, immunotherapy has narrow indications and is not suitable for any cancer patients. It cannot be used by breastfeeding women, organ transplant patients or patients with advanced cachexia; on the other hand, after the use of immunotherapy. Some patients can get obvious relief in a short time, but there are also cases of drug resistance in a short time. These issues still need follow-up research.

\section{Conclusion and Future Perspectives}

Colorectal cancer is still the third largest malignant tumor in the world, and metastasis is the most common cause of death of colorectal cancer, of which liver metastasis is more common. Early diagnosis and treatment of liver metastasis of colorectal cancer is a necessary measure to reduce mortality and improve quality of life and survival time of patients. This paper introduces the research progress of coding genes and ncRNA in the research field of CRLM in recent years, there is an urgent need to understand their mechanism of action in CRLM, looking

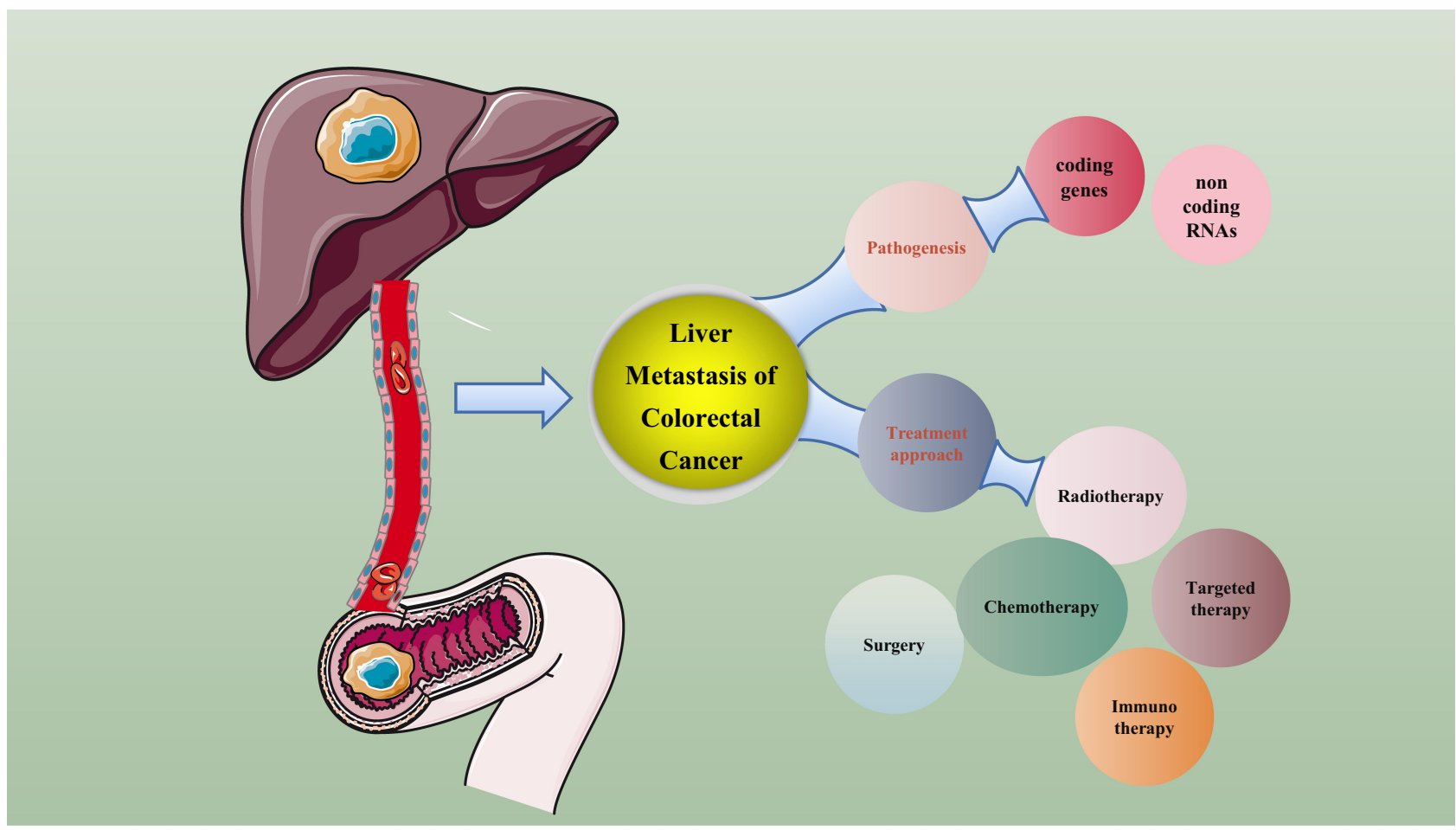

Figure I A summary of mechanism and treatment on liver metastasis of colorectal cancer. 
forward to finding new early diagnostic indicators, and even guiding clinical treatment. Secondly, multidisciplinary comprehensive therapy is one of the main directions in the clinical treatment of liver metastasis of colorectal cancer in recent years. The comprehensive application of surgical treatment, cryotherapy, radiofrequency ablation, absolute ethanol injection, hepatic artery chemoembolization, portal vein chemoembolization, radiotherapy, laser therapy, liver perfusion therapy and immunotherapy will provide a new opportunity for the prognosis of patients with liver metastasis of colorectal cancer (Figure 1).

\section{Acknowledgments}

Wubin Zheng, Fan Wu and Kai Fu are co-first authors.

\section{Funding}

This research was supported by Jiangsu Natural Science Foundation (SBK2019021253) and by the Medical Science and Technology Development Foundation (ZKX18027).

\section{Disclosure}

The authors declare that they have no competing interests.

\section{References}

1. Favoriti P, Carbone G, Greco M, Pirozzi F, Pirozzi RE, Corcione F. Worldwide burden of colorectal cancer: a review. Updates Surg. 2016;68(1):7-11. doi:10.1007/s13304-016-0359-y

2. Bray F, Ferlay J, Soerjomataram I, Siegel RL, Torre LA, Jemal A. Global cancer statistics 2018: GLOBOCAN estimates of incidence and mortality worldwide for 36 cancers in 185 countries. CA Cancer J Clin. 2018;68(6):394-424. doi:10.3322/caac.21492

3. Smith KJ, Williams J, Skelton H. Metastatic adenocarcinoma of the esophagus to the skin: new patterns of tumor recurrence and alternate treatments for palliation. J Cutan Pathol. 2001;28(8):425-431. doi:10.1034/j.1600-0560.2001.028008425.x

4. Petri A, Hohn J, Balogh A, Kovách K, Andrási L, Lázár G. [Surgical treatment of liver metastasis in colorectal cancer with simultaneous liver resection]. Magy Onkol. 2010;54(2):125-128. Hungarian. doi:10.1556/MOnkol.54.2010.2.6

5. Nordlinger B, Sorbye H, Glimelius B, et al. Perioperative chemotherapy with FOLFOX4 and surgery versus surgery alone for resectable liver metastases from colorectal cancer (EORTC Intergroup trial 40983): a randomised controlled trial. Lancet. 2008;371(9617):1007-1016. doi:10.1016/S0140-6736(08)60455-9

6. Scholefield JH, Steele RJ; British Society For Gastroenterology, Association of Coloproctology for Great Britain and Ireland. Guidelines for follow up after resection of colorectal cancer. Gut. 2002;51(Suppl 5):V3-5. doi:10.1136/gut.51.suppl_5.v3

7. Weidle UH, Birzele F, Krüger A. Molecular targets and pathways involved in liver metastasis of colorectal cancer. Clin Exp Metastasis. 2015;32(6):623-635. doi:10.1007/s10585-015-9732-3

8. Fang C, Fan C, Wang C, et al. CD133+CD54+CD44+ circulating tumor cells as a biomarker of treatment selection and liver metastasis in patients with colorectal cancer. Oncotarget. 2016;7 (47):77389-77403. doi:10.18632/oncotarget.12675
9. McAuliffe JC, Qadan M, D'Angelica MI. Hepatic resection, hepatic arterial infusion pump therapy, and genetic biomarkers in the management of hepatic metastases from colorectal cancer. $J$ Gastrointest Oncol. 2015;6(6):699-708. doi:10.3978/j. issn.2078-6891.2015.081

10. Duffy MJ, van Dalen A, Haglund C, et al. Tumour markers in colorectal cancer: European Group on Tumour Markers (EGTM) guidelines for clinical use. Eur J Cancer. 2007;43(9):1348-1360. doi:10.1016/j.ejca.2007.03.021

11. Fidler IJ. The pathogenesis of cancer metastasis: the 'seed and soil' hypothesis revisited. Nat Rev Cancer. 2003;3(6):453-458. doi:10.1038/nrc1098

12. Guttman M, Rinn JL. Modular regulatory principles of large non-coding RNAs. Nature. 2012;482(7385):339-346. doi:10.10 38/nature10887

13. Cech TR, Steitz JA. The noncoding RNA revolution-trashing old rules to forge new ones. Cell. 2014;157(1):77-94. doi:10.1016/j. cell.2014.03.008

14. Quinn JJ, Chang HY. Unique features of long non-coding RNA biogenesis and function. Nat Rev Genet. 2016;17(1):47-62. doi: $10.1038 / \mathrm{nrg} .2015 .10$

15. Fu XD. Non-coding RNA: a new frontier in regulatory biology. Natl Sci Rev. 2014;1(2):190-204. doi:10.1093/nsr/nwu008

16. Liu J, Valencia-Sanchez MA, Hannon GJ, Parker R. MicroRNAdependent localization of targeted mRNAs to mammalian P-bodies. Nat Cell Biol. 2005;7(7):719-723. doi:10.1038/ncb1274

17. $\mathrm{Hu} \mathrm{S}, \mathrm{Wu}$ J, Chen L, Shan G. Signals from noncoding RNAs: unconventional roles for conventional pol III transcripts. Int J Biochem Cell Biol. 2012;44(11):1847-1851. doi:10.1016/j. biocel.2012.07.013

18. Ulitsky I, Bartel DP. lincRNAs: genomics, evolution, and mechanisms. Cell. 2013;154(1):26-46. doi:10.1016/j.cell.2013. 06.020

19. Morris KV, Mattick JS. The rise of regulatory RNA. Nat Rev Genet. 2014;15(6):423-437.

20. Necsulea A, Soumillon M, Warnefors M, et al. The evolution of lncRNA repertoires and expression patterns in tetrapods. Nature. 2014;505(7485):635-640. doi:10.1038/nature12943

21. Mitchell PS, Parkin RK, Kroh EM, et al. Circulating microRNAs as stable blood-based markers for cancer detection. Proc Natl Acad Sci U S A. 2008;105(30):10513-10518. doi:10.1073/ pnas. 0804549105

22. Tsai MC, Spitale RC, Chang HY. Long intergenic noncoding RNAs: new links in cancer progression. Cancer Res. 2011;71 (1):3-7. doi:10.1158/0008-5472.CAN-10-2483

23. DiStefano JK. The emerging role of long noncoding RNAs in human disease. Methods Mol Biol. 2018;1706:91-110.

24. Xue M, Zhuo Y, Shan B. MicroRNAs, long noncoding RNAs, and their functions in human disease. Methods Mol Biol. 2017;1617:1-25.

25. Wapinski O, Chang HY. Long noncoding RNAs and human disease. Trends Cell Biol. 2011;21(6):354-361. doi:10.1016/j. tcb.2011.04.001

26. Lalevée S, Feil R. Long noncoding RNAs in human disease: emerging mechanisms and therapeutic strategies. Epigenomics. 2015;7(6):877-879. doi:10.2217/epi.15.55

27. Planchon SM, Waite KA, Eng C. The nuclear affairs of PTEN. $J$ Cell Sci. 2008;121(3):249-253. doi:10.1242/jcs.022459

28. Ming M, He YY. PTEN in DNA damage repair. Cancer Lett. 2012;319(2):125-129. doi:10.1016/j.canlet.2012.01.003

29. Milella M, Falcone I, Conciatori F, et al. PTEN: multiple functions in human malignant tumors. Front Oncol. 2015;5:24. doi:10.3389/fonc. 2015.00024

30. Chen M, Zhang L, Cui X, et al. Wt1 directs the lineage specification of sertoli and granulosa cells by repressing Sf1 expression. Development. 2017;144(1):44-53. doi:10.1242/dev.144105 
31. Vikhanskaya F. p73 competes with p53 and attenuates its response in a human ovarian cancer cell line. Nucleic Acids Res. 2000;28(2):513-519. doi:10.1093/nar/28.2.513

32. Porter PL, Gown AM, Kramp SG, Coltrera MD. Widespread p53 overexpression in human malignant tumors. An immunohistochemical study using methacarn-fixed, embedded tissue. Am J Pathol. 1992;140(1):145-153.

33. Du $\mathrm{T}$, Niu H. Inhibitory effect of gene combination in a mouse model of colon cancer with liver metastasis. Exp Ther Med. 2014;8(3):913-918. doi:10.3892/etm.2014.1809

34. Furuse M, Fujita K, Hiiragi T, Fujimoto K, Tsukita S. Claudin-1 and -2 : novel integral membrane proteins localizing at tight junctions with no sequence similarity to occludin. $J$ Cell Biol. 1998;141(7):1539-1550. doi:10.1083/jcb.141.7.1539

35. Turksen K, Troy TC. Barriers built on claudins. J Cell Sci. 2004;117(12):2435-2447. doi:10.1242/jcs.01235

36. Kasapkara CS, Tumer L, Okur I, Hasanoglu A. A novel mutation of the claudin 16 gene in familial hypomagnesemia with hypercalciuria and nephrocalcinosis mimicking rickets. Genet Couns. 2011;22(2):187-192.

37. Li J, Chigurupati S, Agarwal R, et al. Possible angiogenic roles for claudin-4 in ovarian cancer. Cancer Biol Ther. 2009;8 (19):1806-1814. doi:10.4161/cbt.8.19.9427

38. Stein U, Walther W, Arlt F, et al. MACC1, a newly identified key regulator of HGF-MET signaling, predicts colon cancer metastasis. Nat Med. 2009;15(1):59-67. doi:10.1038/nm.1889

39. Shimokawa H, Uramoto H, Onitsuka T, et al. Overexpression of MACC1 mRNA in lung adenocarcinoma is associated with postoperative recurrence. J Thorac Cardiovasc Surg. 2011;141 (4):895-898. doi:10.1016/j.jtcvs.2010.09.044

40. Sattler M, Salgia R. c-Met and hepatocyte growth factor: potential as novel targets in cancer therapy. Curr Oncol Rep. 2007;9 (2):102-108. doi:10.1007/s11912-007-0005-4

41. Dubocovich ML, Langer SZ. Negative feed-back regulation of noradrenaline release by nerve stimulation in the perfused cat's spleen: differences in potency of phenoxybenzamine in blocking the pre- and post-synaptic adrenergic receptors. $J$ Physiol. 1974;237(3):505-519. doi:10.1113/jphysiol.1974.sp010495

42. Birchmeier C, Birchmeier W, Gherardi E, Vande Woude GF. Met, metastasis, motility and more. Nat Rev Mol Cell Biol. 2003;4 (12):915-925. doi:10.1038/nrm1261

43. Ge $\mathrm{SH}, \mathrm{Wu} \mathrm{XJ}$, Wang $\mathrm{XH}$, et al. Over-expression of Metastasis-associated in Colon Cancer-1 (MACC1) associates with better prognosis of gastric cancer patients. Chin $J$ Cancer Res. 2011;23(2):153-159. doi:10.1007/s11670-0110153-9

44. Frandsen PM, Madsen LB, Bendixen C, Larsen K. Porcine gamma-synuclein: molecular cloning, expression analysis, chromosomal localization and functional expression. Mol Biol Rep. 2009;36(5):971-979. doi:10.1007/s11033-008-9270-Z

45. Ji H, Liu YE, Jia T, et al. Identification of a breast cancer-specific gene, BCSG1, by direct differential cDNA sequencing. Cancer Res. 1997;57(4):759-764.

46. Ninkina NN, Alimova-Kost MV, Paterson JW, et al. Organization, expression and polymorphism of the human persyn gene. Hum Mol Genet. 1998;7(9):1417-1424. doi:10.1093/hmg/7.9.1417

47. Bruening W, Giasson BI, Klein-Szanto AJ, Lee VM, Trojanowski JQ, Godwin AK. Synucleins are expressed in the majority of breast and ovarian carcinomas and in preneoplastic lesions of the ovary. Cancer. 2000;88(9):2154-2163. doi:10.1002/ (SICI)1097-0142(20000501)88:9<2154::AID-CNCR23>3.0. $\mathrm{CO} ; 2-9$

48. Lu A, Zhang F, Gupta A, Liu J. Blockade of AP1 transactivation abrogates the abnormal expression of breast cancer-specific gene 1 in breast cancer cells. J Biol Chem. 2002;277(35):31364-31372. doi:10.1074/jbc.M201060200
49. Steinmüller L, Cibelli G, Moll JR, Vinson C, Thiel G. Regulation and composition of activator protein 1 (AP-1) transcription factors controlling collagenase and c-Jun promoter activities. Biochem J. 2001;360(3):599-607. doi:10.1042/bj3600599

50. Przybyszewski J, Yaktine AL, Duysen E, et al. Inhibition of phorbol ester-induced AP-1-DNA binding, c-Jun protein and c-jun mRNA by dietary energy restriction is reversed by adrenalectomy in SENCAR mouse epidermis. Carcinogenesis. 2001;22 (9):1421-1427. doi:10.1093/carcin/22.9.1421

51. Inaba S, Li C, Shi YE, Song DQ, Jiang JD, Liu J. Synuclein gamma inhibits the mitotic checkpoint function and promotes chromosomal instability of breast cancer cells. Breast Cancer Res Treat. 2005;94(1):25-35. doi:10.1007/s10549-005-6938-0

52. Liu H, Zhou Y, Boggs SE, Belinsky SA, Liu J. Cigarette smoke induces demethylation of prometastatic oncogene synuclein-gamma in lung cancer cells by downregulation of DNMT3B. Oncogene. 2007;26(40):5900-5910. doi:10.1038/sj.onc.1210400

53. Jiang Y, Liu YE, Lu A, et al. Stimulation of estrogen receptor signaling by gamma synuclein. Cancer Res. 2003;63(14):3899-3903.

54. Guo CG, Sun LC, Liu Q, Xie YB, Wang X. [SNCG expression and clinical significance in colorectal cancer liver metastasis]. Zhonghua Wei Chang Wai Ke Za Zhi. 2012;15 (6):625-628. Chinese.

55. Bonecchi R, Galliera E, Borroni EM, Corsi MM, Locati M, Mantovani A. Chemokines and chemokine receptors: an overview. Front Biosci (Landmark Ed). 2009;14:540-551. doi: $10.2741 / 3261$

56. Bruserud $\varnothing$, Kittang AO. The chemokine system in experimental and clinical hematology. Curr Top Microbiol Immunol. 2010;341:3-12. doi:10.1007/82_2010_18

57. Singh S, Sadanandam A, Singh RK. Chemokines in tumor angiogenesis and metastasis. Cancer Metastasis Rev. 2007;26(3-4):453-467.

58. Balkwill F. Chemokine biology in cancer. Semin Immunol. 2003;15(1):49-55. doi:10.1016/S1044-5323(02)00127-6

59. Tan HX, Gong WZ, Zhou K, et al. CXCR4/TGF- $\beta 1$ mediated hepatic stellate cells differentiation into carcinoma-associated fibroblasts and promoted liver metastasis of colon cancer. Cancer Biol Ther. 2020;21(3):258-268. doi:10.1080/ 15384047.2019.1685157

60. Bie Y, Ge W, Yang Z, et al. The crucial role of CXCL8 and its receptors in colorectal liver metastasis. Dis Markers. 2019;2019:8023460. doi:10.1155/2019/8023460

61. Wightman B, Ha I, Ruvkun G. Posttranscriptional regulation of the heterochronic gene lin-14 by lin- 4 mediates temporal pattern formation in C. elegans. Cell. 1993;75(5):855-862. doi:10.1016/ 0092-8674(93)90530-4

62. Ambros V. The functions of animal microRNAs. Nature. 2004;431(7006):350-355. doi:10.1038/nature02871

63. Bartel DP. MicroRNAs: genomics, biogenesis, mechanism, and function. Cell. 2004;116(2):281-297. doi:10.1016/S00928674(04)00045-5

64. Seto AG, Kingston RE, Lau NC. The coming of age for Piwi proteins. Mol Cell. 2007;26(5):603-609. doi:10.1016/j. molcel.2007.05.021

65. Siomi MC, Sato K, Pezic D, Aravin AA. PIWI-interacting small RNAs: the vanguard of genome defence. Nat Rev Mol Cell Biol. 2011;12(4):246-258. doi:10.1038/nrm3089

66. Salzman J, Gawad C, Wang PL, Lacayo N, Brown PO. Circular RNAs are the predominant transcript isoform from hundreds of human genes in diverse cell types. PLoS One. 2012;7(2):e30733. doi:10.1371/journal.pone.0030733

67. Sanger HL, Klotz G, Riesner D, Gross HJ, Kleinschmidt AK. Viroids are single-stranded covalently closed circular RNA molecules existing as highly base-paired rod-like structures. Proc Natl Acad Sci U S A. 1976;73(11):3852-3856. doi:10.1073/ pnas.73.11.3852 
68. Jeck WR, Sorrentino JA, Wang K, et al. Circular RNAs are abundant, conserved, and associated with ALU repeats. RNA. 2013;19(2):141-157. doi:10.1261/rna.035667.112

69. Denli AM, Tops BB, Plasterk RH, Ketting RF, Hannon GJ. Processing of primary microRNAs by the microprocessor complex. Nature. 2004;432(7014):231-235. doi:10.1038/ nature 03049

70. Ruvkun G. Glimpses of a tiny RNA world. Science. 2001;294 (5543):797-799. doi:10.1126/science.1066315

71. Søkilde R, Vincent M, Møller AK, et al. Efficient identification of miRNAs for classification of tumor origin. J Mol Diagn. 2014;16 (1):106-115. doi:10.1016/j.jmoldx.2013.10.001

72. Pan X, Wang ZX, Wang R. MicroRNA-21: a novel therapeutic target in human cancer. Cancer Biol Ther. 2010;10 (12):1224-1232. doi:10.4161/cbt.10.12.14252

73. Ibrahim SA, Yip GW, Stock C, et al. Targeting of syndecan-1 by microRNA miR-10b promotes breast cancer cell motility and invasiveness via a Rho-GTPase- and E-cadherin-dependent mechanism. Int $J$ Cancer. 2012;131(6):E884-96. doi:10.1002/ ijc. 27629

74. Xue G, Yan HL, Zhang Y, et al. c-Myc-mediated repression of miR-15-16 in hypoxia is induced by increased HIF-2 $\alpha$ and promotes tumor angiogenesis and metastasis by upregulating FGF2. Oncogene. 2015;34(11):1393-1406. doi:10.1038/onc.2014.82

75. Barh D, Malhotra R, Ravi B, Sindhurani P. MicroRNA let-7: an emerging next-generation cancer therapeutic. Curr Oncol. 2010;17(1):70-80. doi:10.3747/co.v17i1.356

76. Jaskiewicz L, Filipowicz W. Role of Dicer in posttranscriptional RNA silencing. Curr Top Microbiol Immunol. 2008;320:77-97. doi:10.1007/978-3-540-75157-1_4

77. Zhang X, Zeng Y. The terminal loop region controls microRNA processing by Drosha and Dicer. Nucleic Acids Res. 2010;38 (21):7689-7697. doi:10.1093/nar/gkq645

78. Salmena L, Poliseno L, Tay Y, Kats L, Pandolfi PP. A ceRNA hypothesis: the Rosetta Stone of a hidden RNA language. Cell. 2011;146(3):353-358. doi:10.1016/j.cell.2011.07.014

79. Demirkan B. The roles of Epithelial-to-Mesenchymal Transition (EMT) and Mesenchymal-to-Epithelial Transition (MET) in breast cancer bone metastasis: potential targets for prevention and treatment. J Clin Med. 2013;2(4):264-282. doi:10.3390/ jcm 2040264

80. Brabletz T. EMT and MET in metastasis: where are the cancer stem cells. Cancer Cell. 2012;22(6):699-701. doi:10.1016/j. ccr.2012.11.009

81. De Craene B, Berx G. Regulatory networks defining EMT during cancer initiation and progression. Nat Rev Cancer. 2013;13 (2):97-110. doi:10.1038/nrc3447

82. Shelton PM, Duran A, Nakanishi Y, et al. The secretion of miR200 s by a PKC $/$ /ADAR2 signaling axis promotes liver metastasis in colorectal cancer. Cell Rep. 2018;23(4):1178-1191. doi:10.1016/j.celrep.2018.03.118

83. Hata T, Mokutani Y, Takahashi $\mathrm{H}$, et al. Identification of microRNA-487b as a negative regulator of liver metastasis by regulation of KRAS in colorectal cancer. Int $J$ Oncol. 2017;50 (2):487-496. doi:10.3892/ijo.2016.3813

84. Okazaki Y, Furuno M, Kasukawa T, et al. Analysis of the mouse transcriptome based on functional annotation of 60,770 full-length cDNAs. Nature. 2002;420(6915):563-573.

85. Rinn JL, Kertesz M, Wang JK, et al. Functional demarcation of active and silent chromatin domains in human HOX loci by noncoding RNAs. Cell. 2007;129(7):1311-1323. doi:10.1016/j. cell.2007.05.022

86. Guttman M, Amit I, Garber M, et al. Chromatin signature reveals over a thousand highly conserved large non-coding RNAs in mammals. Nature. 2009;458(7235):223-227. doi:10.1038/ nature 07672
87. Poliseno L, Salmena L, Zhang J, Carver B, Haveman WJ, Pandolfi PP. A coding-independent function of gene and pseudogene mRNAs regulates tumour biology. Nature. 2010;465 (7301):1033-1038. doi:10.1038/nature09144

88. Wang KC, Chang HY. Molecular mechanisms of long noncoding RNAs. Mol Cell. 2011;43(6):904-914. doi:10.1016/j. molcel.2011.08.018

89. Zhang F, Zhang L, Zhang C. Long noncoding RNAs and tumorigenesis: genetic associations, molecular mechanisms, and therapeutic strategies. Tumour Biol. 2016;37(1):163-175. doi:10.1007/ s13277-015-4445-4

90. Kwok ZH, Tay Y. Long noncoding RNAs: lincs between human health and disease. Biochem Soc Trans. 2017;45(3):805-812. doi:10.1042/BST20160376

91. Miyoshi A, Kitajima Y, Sumi K, et al. Snail and SIP1 increase cancer invasion by upregulating MMP family in hepatocellular carcinoma cells. $\mathrm{Br} J$ Cancer. 2004;90(6):1265-1273. doi:10.1038/sj.bjc. 6601685

92. Chen DL, Lu YX, Zhang JX, et al. Long non-coding RNA UICLM promotes colorectal cancer liver metastasis by acting as a ceRNA for microRNA-215 to regulate ZEB2 expression. Theranostics. 2017;7(19):4836-4849. doi:10.7150/thno.20942

93. McElwee JL, Mohanan S, Horibata S, et al. PAD2 overexpression in transgenic mice promotes spontaneous skin neoplasia. Cancer Res. 2014;74(21):6306-6317. doi:10.1158/0008-5472.CAN-14-0749

94. Tanday S. Targeting PADI2 could stop the progression of myeloma. Lancet Oncol. 2016;17(8):e325. doi:10.1016/S14702045(16)30314-X

95. Wang H, Xu B, Zhang X, Zheng Y, Zhao Y, Chang X. PADI2 gene confers susceptibility to breast cancer and plays tumorigenic role via ACSL4, BINC3 and CA9 signaling. Cancer Cell Int. 2016;16:61. doi:10.1186/s12935-016-0335-0

96. Wang G, Mao W, Zheng S, Ye J. Epidermal growth factor receptor-regulated miR-125a-5p-a metastatic inhibitor of lung cancer. FEBS J. 2009;276(19):5571-5578. doi:10.1111/j.17424658.2009.07238.x

97. Sun Y, Liu X, Zhang Q, et al. Oncogenic potential of TSTA3 in breast cancer and its regulation by the tumor suppressors miR-125a-5p and miR-125b. Tumour Biol. 2016;37 (4):4963-4972. doi:10.1007/s13277-015-4178-4

98. Xu Y, Huang Z, Liu Y. Reduced miR-125a-5p expression is associated with gastric carcinogenesis through the targeting of E2F3. Mol Med Rep. 2014;10(5):2601-2608. doi:10.3892/ mmr.2014.2567

99. Kim JK, Noh JH, Jung KH, et al. Sirtuin7 oncogenic potential in human hepatocellular carcinoma and its regulation by the tumor suppressors MiR-125a-5p and MiR-125b. Hepatology. 2013;57 (3):1055-1067. doi:10.1002/hep.26101

100. Nishida N, Mimori K, Fabbri M, et al. MicroRNA-125a-5p is an independent prognostic factor in gastric cancer and inhibits the proliferation of human gastric cancer cells in combination with trastuzumab. Clin Cancer Res. 2011;17(9):2725-2733. doi:10.1158/1078-0432.CCR-10-2132

101. Chen D, Sun Q, Zhang L, et al. The lncRNA HOXA11-AS functions as a competing endogenous RNA to regulate PADI2 expression by sponging miR-125a-5p in liver metastasis of colorectal cancer. Oncotarget. 2017;8(41):70642-70652. doi:10.18632/ oncotarget.19956

102. Yamahashi Y, Hatakeyama M. PAR1b takes the stage in the morphogenetic and motogenetic activity of Helicobacter pylori CagA oncoprotein. Cell Adh Migr. 2013;7(1):11-18. doi:10.4161/ cam. 21936

103. Yang $H$, Zhang $H$, Yang $Y$, et al. Hypoxia induced exosomal circRNA promotes metastasis of colorectal cancer via targeting GEF-H1/RhoA axis. Theranostics. 2020;10(18):8211-8226. doi: $10.7150 /$ thno. 44419 
104. Ozturk N, Singh I, Mehta A, Braun T, Barreto G. HMGA proteins as modulators of chromatin structure during transcriptional activation. Front Cell Dev Biol. 2014;2:5. doi:10.3389/ fcell.2014.00005

105. Sgarra R, Rustighi A, Tessari MA, et al. Nuclear phosphoproteins HMGA and their relationship with chromatin structure and cancer. FEBS Lett. 2004;574(1-3):1-8. doi:10.1016/j.febslet.2004.08.013

106. Frost L, Baez MA, Harrilal C, Garabedian A, Fernandez-Lima F, Leng $\mathrm{F}$. The dimerization state of the mammalian high mobility group protein AT-hook 2 (HMGA2). PLoS One. 2015;10(6): e0130478. doi:10.1371/journal.pone.0130478

107. Galdiero F, Romano A, Pasquinelli R, et al. Detection of high mobility group A2 specific mRNA in the plasma of patients affected by epithelial ovarian cancer. Oncotarget. 2015;6 (22):19328-19335. doi:10.18632/oncotarget.2896

108. Chen RX, Chen X, Xia LP, et al. N6-methyladenosine modification of circNSUN2 facilitates cytoplasmic export and stabilizes HMGA2 to promote colorectal liver metastasis. Nat Commun. 2019;10(1):4695. doi:10.1038/s41467-019-12651-2

109. Dexiang Z, Li R, Ye W, et al. Outcome of patients with colorectal liver metastasis: analysis of 1613 consecutive cases. Ann Surg Oncol. 2012;19(9):2860-2868. doi:10.1245/s10434-012-2356-9

110. Adam R, Hoti E, Folprecht G, Benson AB. Accomplishments in 2008 in the management of curable metastatic colorectal cancer. Gastrointest Cancer Res. 2009;3(5 Supplement 2):S15-22.

111. Enquist IB, Good Z, Jubb AM, et al. Lymph node-independent liver metastasis in a model of metastatic colorectal cancer. Nat Commun. 2014;5:3530. doi:10.1038/ncomms4530

112. Zhang Y, Davis C, Ryan J, Janney C, Peña MM. Development and characterization of a reliable mouse model of colorectal cancer metastasis to the liver. Clin Exp Metastasis. 2013;30 (7):903-918. doi:10.1007/s10585-013-9591-8

113. Lee HS, Kim HO, Hong YS, et al. Prognostic value of metabolic parameters in patients with synchronous colorectal cancer liver metastasis following curative-intent colorectal and hepatic surgery. $J$ Nucl Med. 2014;55(4):582-589. doi:10.2967/ jnumed.113.128629

114. Xiao Y, Freeman GJ. The microsatellite instable subset of colorectal cancer is a particularly good candidate for checkpoint blockade immunotherapy. Cancer Discov. 2015;5(1):16-18. doi:10.1158/2159-8290.CD-14-1397

115. Wu T, Dai Y. Tumor microenvironment and therapeutic response. Cancer Lett. 2017;387:61-68. doi:10.1016/j.canlet.2016.01.043

116. Dougan M, Dougan SK. Targeting immunotherapy to the tumor microenvironment. J Cell Biochem. 2017;118(10):3049-3054. doi: $10.1002 /$ jcb. 26005

117. Wrobel P, Ahmed S. Current status of immunotherapy in metastatic colorectal cancer. Int J Colorectal Dis. 2019;34(1):13-25. doi:10.1007/s00384-018-3202-8

118. Andersen R, Donia M, Westergaard MC, Pedersen M, Hansen M, Svane IM. Tumor infiltrating lymphocyte therapy for ovarian cancer and renal cell carcinoma. Hum Vaccin Immunother. 2015;11(12):2790-2795. doi:10.1080/21645515.2015.1075106

119. Veluchamy JP, Lopez-Lastra S, Spanholtz J, et al. In vivo efficacy of umbilical cord blood stem cell-derived NK cells in the treatment of metastatic colorectal cancer. Front Immunol. 2017;8:87. doi:10.3389/fimmu.2017.00087

120. Katz SC, Burga RA, McCormack E, et al. Phase I hepatic immunotherapy for metastases study of intra-arterial chimeric antigen receptor-modified T-cell therapy for CEA+ liver metastases. Clin Cancer Res. 2015;21(14):3149-3159. doi:10.1158/1078-0432. CCR-14-1421

121. Quiroga D, Lyerly HK, Morse MA. Deficient mismatch repair and the role of immunotherapy in metastatic colorectal cancer Curr Treat Options Oncol. 2016;17(8):41. doi:10.1007/s11864016-0414-4
122. Yaghoubi N, Soltani A, Ghazvini K, Hassanian SM, Hashemy SI. PD-1 inhibitor bests chemo for colorectal cancer. Cancer Discov. 2020;10(7):OF2. doi:10.1158/2159-8290.CD-NB2020-051

123. Herbst RS, Soria JC, Kowanetz M, et al. Predictive correlates of response to the anti-PD-L1 antibody MPDL3280A in cancer patients. Nature. 2014;515(7528):563-567. doi:10.1038/nature14011

124. Bu P, Chen KY, Xiang K, et al. Aldolase B-mediated fructose metabolism drives metabolic reprogramming of colon cancer liver metastasis. Cell Metab. 2018;27(6):1249-1262.e4. doi:10.1016/j. cmet.2018.04.003

125. Na H, Liu X, Li X, et al. Novel roles of DC-SIGNR in colon cancer cell adhesion, migration, invasion, and liver metastasis. $J$ Hematol Oncol. 2017;10(1):28.

126. Li Y, Xi Y, Zhu G, et al. Downregulated IGFBP7 facilitates liver metastasis by modulating epithelial-mesenchymal transition in colon cancer. Oncol Rep. 2019;42(5):1935-1945. doi:10.3892/ or.2019.7303

127. Chai WX, Sun LG, Dai FH, Shao HS, Zheng NG, Cai HY. Inhibition of PRRX2 suppressed colon cancer liver metastasis via inactivation of $\mathrm{Wnt} / \beta$-catenin signaling pathway. Pathol Res Pract. 2019;215(10):152593. doi:10.1016/j.prp.2019.152593

128. Urosevic J, Blasco MT, Llorente A, et al. ERK1/2 signaling induces upregulation of ANGPT2 and CXCR4 to mediate liver metastasis in colon cancer. Cancer Res. 2020;80(21):4668-4680. doi:10.1158/0008-5472.CAN-19-4028

129. Lichao S, Liang P, Chunguang G, Fang L, Zhihua Y, Yuliang R. Overexpression of PTGIS could predict liver metastasis and is correlated with poor prognosis in colon cancer patients. Pathol Oncol Res. 2012;18(3):563-569. doi:10.1007/s12253-011-9478-4

130. Ding YL, Zhou Y, Xiang L, Ji ZP, Luo ZH. Expression of glioma-associated oncogene homolog 1 is associated with invasion and postoperative liver metastasis in colon cancer. Int $\mathrm{J} \mathrm{Med}$ Sci. 2012;9(5):334-338. doi:10.7150/ijms.4553

131. Yamamoto M, Kikuchi H, Ohta M, et al. TSU68 prevents liver metastasis of colon cancer xenografts by modulating the premetastatic niche. Cancer Res. 2008;68(23):9754-9762. doi:10.1158/ 0008-5472.CAN-08-1748

132. Min BS, Kim NK, Jeong HC, Chung HC. High levels of serum VEGF and TIMP-1 are correlated with colon cancer liver metastasis and intrahepatic recurrence after liver resection. Oncol Lett. 2012;4(1):123-130. doi:10.3892/ol.2012.691

133. Tokunaga T, Oshika Y, Abe Y, et al. Vascular endothelial growth factor (VEGF) mRNA isoform expression pattern is correlated with liver metastasis and poor prognosis in colon cancer. $\mathrm{Br}$ J Cancer. 1998;77(6):998-1002. doi:10.1038/bjc.1998.164

134. Okamoto K, Oshika Y, Fukushima Y, et al. Inhibition of liver metastasis of colon cancer by in vivo administration of anti-vascular endothelial growth factor antibody. Oncol Rep. 1999;6(3):553-556. doi:10.3892/or.6.3.553

135. Warren RS, Yuan H, Matli MR, Gillett NA, Ferrara N. Regulation by vascular endothelial growth factor of human colon cancer tumorigenesis in a mouse model of experimental liver metastasis. J Clin Invest. 1995;95(4):1789-1797. doi:10.1172/JCI117857

136. Ding YL, Fu QY, Tang SF, Zhang JL, Li ZY, Li ZT. [Effect of stromal cell-derived factor-1 and its receptor CXCR4 on liver metastasis of human colon cancer]. Zhonghua Wai Ke Za Zhi. 2009;47(3):210-213. Chinese.

137. Huang ZL, Liu HY. [Expression of galectin-3 in liver metastasis of colon cancer and the inhibitory effect of modified citrus pectin]. Nan Fang Yi Ke Da Xue Xue Bao. 2008;28 (8):1358-1361.

138. Fang YJ, Lu ZH, Wang GQ, et al. Elevated expressions of MMP7, TROP2, and survivin are associated with survival, disease recurrence, and liver metastasis of colon cancer. Int J Colorectal Dis. 2009;24(8):875-884. doi:10.1007/s00384009-0725-z 
139. Wen J, Matsumoto K, Taniura N, Tomioka D, Nakamura T. Hepatic gene expression of NK4, an HGF-antagonist/angiogenesis inhibitor, suppresses liver metastasis and invasive growth of colon cancer in mice. Cancer Gene Ther. 2004;11(6):419-430. doi:10.1038/sj.cgt.7700705

140. Babyatsky M, Lin J, Yio X, et al. Trefoil factor-3 expression in human colon cancer liver metastasis. Clin Exp Metastasis. 2009;26(2):143-151. doi:10.1007/s10585-008-9224-9

141. Yamauchi K, Ogata Y, Nagase H, Shirouzu K. Inhibition of liver metastasis from orthotopically implanted colon cancer in nude mice by transfection of the TIMP-1 gene into KM12SM cells. Surg Today. 2001;31(9):791-798. doi:10.1007/s005950170049

142. Murata S, Yanagisawa K, Fukunaga K, et al. Fatty acid synthase inhibitor cerulenin suppresses liver metastasis of colon cancer in mice. Cancer Sci. 2010;101(8):1861-1865. doi:10.1111/j.13497006.2010.01596.x

143. Matsushita Y, Kitajima S, Goto M, et al. Selectins induced by interleukin-1beta on the human liver endothelial cells act as ligands for sialyl Lewis X-expressing human colon cancer cell metastasis. Cancer Lett. 1998;133(2):151-160. doi:10.1016/ S0304-3835(98)00220-1

144. Li M, Lin YM, Hasegawa S, et al. Genes associated with liver metastasis of colon cancer, identified by genome-wide cDNA microarray. Int J Oncol. 2004;24(2):305-312.

145. Kitamura T, Fujishita T, Loetscher P, et al. Inactivation of chemokine (C-C motif) receptor 1 (CCR1) suppresses colon cancer liver metastasis by blocking accumulation of immature myeloid cells in a mouse model. Proc Natl Acad Sci U S A. 2010;107 (29):13063-13068. doi:10.1073/pnas.1002372107

146. Oba K, Konno H, Tanaka T, et al. Prevention of liver metastasis of human colon cancer by selective matrix metalloproteinase inhibitor MMI-166. Cancer Lett. 2002;175(1):45-51. doi:10. 1016/S0304-3835(01)00726-1

147. Oshima T, Kunisaki C, Yoshihara K, et al. Clinicopathological significance of the gene expression of matrix metalloproteinases and reversion-inducing cysteine-rich protein with Kazal motifs in patients with colorectal cancer: MMP-2 gene expression is a useful predictor of liver metastasis from colorectal cancer. Oncol Rep. 2008;19(5):1285-1291.

148. Suwa D, Konno H, Tanaka T, Urano T. Intraperitoneal infusion of recombinant plasminogen activator inhibitor type 2 induced apoptosis in implanted human colon cancer and inhibited its growth and liver metastasis. Anticancer Res. 2008;28 (2A):693-698.

149. Zhang B, Halder SK, Zhang S, Datta PK. Targeting transforming growth factor-beta signaling in liver metastasis of colon cancer. Cancer Lett. 2009;277(1):114-120. doi:10.1016/j.canlet.2008. 11.035

150. Ishii M, Iwai M, Harada $Y$, et al. Soluble TRAIL gene and actinomycin D synergistically suppressed multiple metastasis of TRAIL-resistant colon cancer in the liver. Cancer Lett. 2007;245 (1-2):134-143. doi:10.1016/j.canlet.2005.12.040

151. Aykut B, Ochs M, Radhakrishnan P, et al. EMX2 gene expression predicts liver metastasis and survival in colorectal cancer. $B M C$ Cancer. 2017;17(1):555. doi:10.1186/s12885-017-3556-2

152. Teraoku H, Morine Y, Ikemoto T, et al. Role of thrombospondin-1 expression in colorectal liver metastasis and its molecular mechanism. J Hepatobiliary Pancreat Sci. 2016;23(9):565-573. doi:10.1002/jhbp. 376

153. Kim CW, Roh SA, Tak KH, et al. ZKSCAN3 facilitates liver metastasis of colorectal cancer associated with CEA-expressing tumor. Anticancer Res. 2016;36(5):2397-2406.

154. Liu $\mathrm{H}, \mathrm{Xu} \mathrm{Y,} \mathrm{Zhang} \mathrm{Q,} \mathrm{et} \mathrm{al.} \mathrm{Prognostic} \mathrm{significance} \mathrm{of}$ TBL1XR1 in predicting liver metastasis for early stage colorectal cancer. Surg Oncol. 2017;26(1):13-20. doi:10.1016/j.suronc. 2016.12.003
155. Ai X, Wu Y, Zhang W, et al. Targeting the ERK pathway reduces liver metastasis of Smad4-inactivated colorectal cancer. Cancer Biol Ther. 2013;14(11):1059-1067. doi:10.4161/cbt.26427

156. Kawashita Y, Morine Y, Ikemoto T, et al. Loss of Fbxw7 expression is a predictor of recurrence in colorectal liver metastasis. J Hepatobiliary Pancreat Sci. 2017;24(10):576-583. doi:10.1002/ jhbp. 500

157. Ding Q, Chang CJ, Xie X, et al. APOBEC3G promotes liver metastasis in an orthotopic mouse model of colorectal cancer and predicts human hepatic metastasis. J Clin Invest. 2011;121 (11):4526-4536. doi:10.1172/JCI45008

158. Jiang T, Zhu A, Zhu Y, Piao D. Clinical implications of AEG-1 in liver metastasis of colorectal cancer. Med Oncol. 2012;29 (4):2858-2863. doi:10.1007/s12032-012-0186-z

159. Huang MY, Yen LC, Liu HC, et al. Significant overexpression of DVL1 in Taiwanese colorectal cancer patients with liver metastasis. Int $J$ Mol Sci. 2013;14(10):20492-20507. doi:10.3390/ijms141020492

160. Georges R, Bergmann F, Hamdi H, et al. Sequential biphasic changes in claudin 1 and claudin4 expression are correlated to colorectal cancer progression and liver metastasis. J Cell Mol Med. 2012;16(2):260-272. doi:10.1111/j.1582-4934.2011.01289.x

161. Liu YL, Yang YM, Xu H, Dong XS. Aberrant expression of USP22 is associated with liver metastasis and poor prognosis of colorectal cancer. J Surg Oncol. 2011;103(3):283-289. doi:10.1002/jso. 21802

162. Ge Y, Meng X, Zhou Y, Zhang J, Ding Y. Positive MACC1 expression correlates with invasive behaviors and postoperative liver metastasis in colon cancer. Int J Clin Exp Med. 2015;8 (1):1094-1100.

163. Huang MY, Wang HM, Chang HJ, Hsiao CP, Wang JY, Lin SR. Overexpression of S100B, TM4SF4, and OLFM4 genes is correlated with liver metastasis in Taiwanese colorectal cancer patients. DNA Cell Biol. 2012;31(1):43-49. doi:10.1089/ dna.2011.1264

164. Cho YB, Lee WY, Choi SJ, et al. CC chemokine ligand 7 expression in liver metastasis of colorectal cancer. Oncol Rep. 2012;28(2):689-694. doi:10.3892/or.2012.1815

165. Hu XT, Chen W, Wang D, et al. The proteasome subunit PSMA7 located on the 20q13 amplicon is overexpressed and associated with liver metastasis in colorectal cancer. Oncol Rep. 2008;19 (2):441-446.

166. Sun Y, Li Z, Xu Z. [Association of expression of HGF and its receptor c-Met to primary colorectal cancers with synchronous liver metastasis]. Zhonghua Wei Chang Wai Ke Za Zhi. 2014;17 (6):598-601. Chinese.

167. Komatsu K, Kobune-Fujiwara Y, Andoh A, et al. Increased expression of S100A6 at the invading fronts of the primary lesion and liver metastasis in patients with colorectal adenocarcinoma. Br J Cancer. 2000;83(6):769-774. doi:10.1054/bjoc.2000.1356

168. Nakayama N, Yamashita K, Tanaka T, et al. Genomic gain of the PRL-3 gene may represent poor prognosis of primary colorectal cancer, and associate with liver metastasis. Clin Exp Metastasis. 2016;33(1):3-13. doi:10.1007/s10585-015-9749-7

169. Tanaka T, Kaida T, Yokoi K, et al. Critical relevance of genomic gains of PRL-3/EGFR/c-myc pathway genes in liver metastasis of colorectal cancer. Oncol Lett. 2019;17(1):1257-1266. doi:10.3892/ol.2018.9728

170. Huang CJ, Teng HW, Chien CC, Lin JK, Yang SH. Prognostic significance of C-reactive protein polymorphism and KRAS/ BRAF in synchronous liver metastasis from colorectal cancer. PLoS One. 2014;8(6):e65117. doi:10.1371/journal.pone.0065117

171. Shoji Y, Takamura H, Ninomiya I, et al. The embryonic stem cell-specific transcription factor ZFP57 promotes liver metastasis of colorectal cancer. J Surg Res. 2019;237:22-29. doi:10.1016/j. jss.2018.11.014 
172. Liang L, Wei Y, Ren L, Zhong YS, Xu JM. [A study of the relationship between the mutation of PIK3CA, PTEN and the occurrence of liver metastasis of colorectal cancer: survival analysis]. Zhonghua Wai Ke Za Zhi. 2012;50 (11):1007-1010. Chinese.

173. Watanabe T, Kobunai T, Yamamoto Y, et al. Prediction of liver metastasis after colorectal cancer using reverse transcription-polymerase chain reaction analysis of 10 genes. Eur $J$ Cancer. 2010;46(11):2119-2126. doi:10.1016/j. ejca.2010.04.019

174. Ito D, Yogosawa $\mathrm{S}$, Mimoto $\mathrm{R}$, et al. Dual-specificity tyrosine-regulated kinase 2 is a suppressor and potential prognostic marker for liver metastasis of colorectal cancer. Cancer Sci. 2017;108(8):1565-1573. doi:10.1111/cas.13280

175. Lin Q, Wei Y, Zhong Y, et al. Aberrant expression of sphingosine-1-phosphate receptor 1 correlates with metachronous liver metastasis and poor prognosis in colorectal cancer. Tumour Biol. 2014;35(10):9743-9750. doi:10.1007/s13277-014-2267-4

176. Kee JY, Ito A, Hojo S, et al. Chemokine CXCL16 suppresses liver metastasis of colorectal cancer via augmentation of tumor-infiltrating natural killer T cells in a murine model. Oncol Rep. 2013;29(3):975-982. doi:10.3892/or.2012.2185

177. Oshima T, Kawasaki T, Ohashi R, et al. Downregulated P1 promoter-driven hepatocyte nuclear factor-4alpha expression in human colorectal carcinoma is a new prognostic factor against liver metastasis. Pathol Int. 2007;57(2):82-90. doi:10.1111/ j.1440-1827.2006.02061.x

178. Chu PC, Lin PC, Wu HY, et al. Mutant KRAS promotes liver metastasis of colorectal cancer, in part, by upregulating the MEK-Sp1DNMT1-miR-137-YB-1-IGF-IR signaling pathway. Oncogene. 2018;37(25):3440-3455. doi:10.1038/s41388-018-0222-3

179. Nakamura M, Miyamoto S, Maeda H, et al. Low levels of insulinlike growth factor type 1 receptor expression at cancer cell membrane predict liver metastasis in Dukes' C human colorectal cancers. Clin Cancer Res. 2004;10(24):8434-8441. doi:10.1158/ 1078-0432.CCR-04-0430

180. Tóth C, Sükösd F, Valicsek E, Herpel E, Schirmacher P, Tiszlavicz L. Loss of CDX2 gene expression is associated with DNA repair proteins and is a crucial member of the Wnt signaling pathway in liver metastasis of colorectal cancer. Oncol Lett. 2018;15(3):3586-3593. doi:10.3892/ol.2018.7756

181. Xu H, Wang C, Song $\mathrm{H}, \mathrm{Xu} \mathrm{Y}$, Ji G. RNA-Seq profiling of circular RNAs in human colorectal Cancer liver metastasis and the potential biomarkers. Mol Cancer. 2019;18(1):8. doi:10.1186/ s12943-018-0932-8

182. Wang Q, Shi L, Shi K, et al. CircCSPP1 functions as a ceRNA to promote colorectal carcinoma cell EMT and liver metastasis by upregulating COL1A1. Front Oncol. 2020;10:850. doi:10.3389/ fonc. 2020.00850

183. Shi L, Tao C, Tang Y, Xia Y, Li X, Wang X. Hypoxia-induced hsa_circ_0000826 is linked to liver metastasis of colorectal cancer. $J$ Clin Lab Anal. 2020;34(9):e23405. doi:10.1002/jcla.23405

184. Zhi Q, Wan D, Ren R, et al. Circular RNA profiling identifies circ102049 as a key regulator of colorectal liver metastasis. Mol Oncol. 2020;15:623-641. doi:10.1002/1878-0261.12840

185. Ye LC, Ren L, Qiu JJ, et al. Aberrant expression of long noncoding RNAs in colorectal cancer with liver metastasis. Tumour Biol. 2015;36(11):8747-8754. doi:10.1007/s13277-015-3627-4

186. Shan Y, Ma J, Pan Y, Hu J, Liu B, Jia L. LncRNA SNHG7 sponges miR-216b to promote proliferation and liver metastasis of colorectal cancer through upregulating GALNT1. Cell Death Dis. 2018;9(7):722. doi:10.1038/s41419-018-0759-7

187. Zhang P, Shi L, Song L, et al. LncRNA CRNDE and lncRNA SNHG7 are promising biomarkers for prognosis in synchronous colorectal liver metastasis following hepatectomy. Cancer Manag Res. 2020;12:1681-1692. doi:10.2147/CMAR.S233147
188. Huang L, Lin H, Kang L, et al. Aberrant expression of long noncoding RNA SNHG15 correlates with liver metastasis and poor survival in colorectal cancer. J Cell Physiol. 2019;234 (5):7032-7039. doi: $10.1002 /$ jcp. 27456

189. Zhu X, Bu F, Tan T, et al. Long noncoding RNA RP11-757G1.5 sponges miR-139-5p and upregulates YAP1 thereby promoting the proliferation and liver, spleen metastasis of colorectal cancer. J Exp Clin Cancer Res. 2020;39(1):207. doi:10.1186/s13046-02001717-5

190. Wang L, Wei Z, Wu K, et al. Long noncoding RNA B3GALT5-AS1 suppresses colon cancer liver metastasis via repressing microRNA-203. Aging (Albany NY). 2018;10 (12):3662-3682. doi:10.18632/aging. 101628

191. Bleau AM, Redrado M, Nistal-Villan E, et al. miR-146a targets c-met and abolishes colorectal cancer liver metastasis. Cancer Lett. 2018;414:257-267. doi:10.1016/j.canlet.2017.11.008

192. Iguchi T, Nambara S, Masuda T, et al. miR-146a polymorphism (rs2910164) predicts colorectal cancer patients' susceptibility to liver metastasis. PLoS One. 2016;11(11):e0165912. doi:10.1371/ journal.pone. 0165912

193. Lai H, Zhang J, Zuo H, et al. Overexpression of miR-17 is correlated with liver metastasis in colorectal cancer. Medicine (Baltimore). 2020;99(9):e19265. doi:10.1097/MD.000000000 0019265

194. Zhang Y, He X, Liu Y, et al. microRNA-320a inhibits tumor invasion by targeting neuropilin 1 and is associated with liver metastasis in colorectal cancer. Oncol Rep. 2012;27(3):685-694. doi:10.3892/or.2011.1561

195. Sun L, Liu X, Pan B, et al. Serum exosomal miR-122 as a potential diagnostic and prognostic biomarker of colorectal cancer with liver metastasis. J Cancer. 2020;11(3):630-637. doi:10.7150/jca.33022

196. Vychytilova-Faltejskova P, Pesta M, Radova L, et al. Genomewide microRNA expression profiling in primary tumors and matched liver metastasis of patients with colorectal cancer. Cancer Genomics Proteomics. 2016;13(4):311-316.

197. Iino I, Kikuchi H, Miyazaki S, et al. Effect of miR-122 and its target gene cationic amino acid transporter 1 on colorectal liver metastasis. Cancer Sci. 2013;104(5):624-630. doi:10.1111/cas.12122

198. Takeyama H, Yamamoto H, Yamashita S, et al. Decreased miR-340 expression in bone marrow is associated with liver metastasis of colorectal cancer. Mol Cancer Ther. 2014;13 (4):976-985. doi:10.1158/1535-7163.MCT-13-0571

199. Cristóbal I, Rincón R, Manso R, et al. Deregulation of miR-200b, miR-200c and miR-429 indicates its potential relevant role in patients with colorectal cancer liver metastasis. J Surg Oncol. 2014;110(4):484-485. doi:10.1002/jso.23661

200. Yin J, Bai Z, Song J, et al. Differential expression of serum miR-126, miR-141 and miR-21 as novel biomarkers for early detection of liver metastasis in colorectal cancer. Chin J Cancer Res. 2014;26 (1):95-103. doi:10.3978/j.issn.1000-9604.2014.02.07

201. Luo HY, Yang Z, Wei W, et al. Enzymatically synthesized poly (amino-co-ester) polyplexes for systemic delivery of pcDNA-miRNA-214 to suppress colorectal cancer liver metastasis. $J$ Mater Chem B. 2018;6(40):6365-6376. doi:10.1039/C8TB01932K

202. Cristóbal I, Caramés C, Madoz-Gúrpide J, Rojo F, Aguilera O, García-Foncillas J. Downregulation of miR-214 is specific of liver metastasis in colorectal cancer and could play a role determining the metastatic niche. Int J Colorectal Dis. 2014;29(7):885. doi:10.1007/s00384-014-1872-4

203. Chen DL, Wang ZQ, Zeng ZL, et al. Identification of microRNA-214 as a negative regulator of colorectal cancer liver metastasis by way of regulation of fibroblast growth factor receptor 1 expression. Hepatology. 2014;60(2):598-609. doi:10.1002/ hep. 27118 
204. Cui Z, Tang J, Chen J, Wang Z. Hsa-miR-574-5p negatively regulates MACC-1 expression to suppress colorectal cancer liver metastasis. Cancer Cell Int. 2014;14:47. doi:10.1186/1475-2867-14-47

205. Ji D, Chen Z, Li M, et al. MicroRNA-181a promotes tumor growth and liver metastasis in colorectal cancer by targeting the tumor suppressor WIF-1. Mol Cancer. 2014;13:86. doi:10.1186/ 1476-4598-13-86

206. Li W, Chang J, Wang S, et al. miRNA-99b-5p suppresses liver metastasis of colorectal cancer by down-regulating mTOR. Oncotarget. 2015;6(27):24448-24462. doi:10.18632/oncotarget.4423

207. Cristóbal I, Torrejón B, González-Alonso P, Manso R, Rojo F, García-Foncillas J. Downregulation of miR-138 as a contributing mechanism to Lcn-2 overexpression in colorectal cancer with liver metastasis. World J Surg. 2016;40(4):1021-1022. doi:10. 1007/s00268-015-3241-z

208. Jiang H, Liu J, Chen Y, Ma C, Li B, Hao T. Up-regulation of mir-10b predicate advanced clinicopathological features and liver metastasis in colorectal cancer. Cancer Med. 2016;5 (10):2932-2941. doi:10.1002/cam4.789

209. Kingham TP, Nguyen H, Zheng J, et al. MicroRNA-203 predicts human survival after resection of colorectal liver metastasis. Oncotarget. 2017;8(12):18821-18831. doi:10.18632/oncotarget. 13816

210. Murakami T, Kikuchi H, Ishimatsu H, et al. Tenascin C in colorectal cancer stroma is a predictive marker for liver metastasis and is a potent target of miR-198 as identified by microRNA analysis. Br J Cancer. 2017;117(9):1360-1370. doi:10.1038/bjc.2017.291

211. Makondi PT, Wei PL, Huang CY, Chang YJ. Development of novel predictive miRNA/target gene pathways for colorectal cancer distance metastasis to the liver using a bioinformatic approach. PLoS One. 2019;14(2):e0211968. doi:10.1371/journal. pone. 0211968
212. Liu J, Li H, Sun L, et al. Epigenetic alternations of microRNAs and DNA methylation contribute to liver metastasis of colorectal cancer. Dig Dis Sci. 2019;64(6):1523-1534. doi:10.1007/s10620018-5424-6

213. Sahu SS, Dey S, Nabinger SC, et al. The role and therapeutic potential of miRNAs in colorectal liver metastasis. Sci Rep. 2019;9(1):15803. doi:10.1038/s41598-019-52225-2

214. Wang D, Wang X, Si M, et al. Exosome-encapsulated miRNAs contribute to CXCL12/CXCR4-induced liver metastasis of colorectal cancer by enhancing M2 polarization of macrophages. Cancer Lett. 2020;474:36-52. doi:10.1016/j.canlet.2020.01.005

215. Sakai H, Sato A, Aihara Y, et al. MKK7 mediates miR-493dependent suppression of liver metastasis of colon cancer cells. Cancer Sci. 2014;105(4):425-430. doi:10.1111/cas. 12380

216. Geng L, Chaudhuri A, Talmon G, et al. MicroRNA-192 suppresses liver metastasis of colon cancer. Oncogene. 2014;33 (46):5332-5340. doi:10.1038/onc.2013.478

217. Zhao S, Mi Y, Guan B, et al. Tumor-derived exosomal miR-934 induces macrophage M2 polarization to promote liver metastasis of colorectal cancer. $J$ Hematol Oncol. 2020;13(1):156. doi:10.1186/s13045-020-00991-2

218. Machackova T, Vychytilova-Faltejskova P, Souckova K, et al. MiR-215-5p reduces liver metastasis in an experimental model of colorectal cancer through regulation of ECM-receptor interactions and focal adhesion. Cancers (Basel). 2020;12(12):3518. doi:10.3390/cancers 12123518

\section{Publish your work in this journal}

OncoTargets and Therapy is an international, peer-reviewed, open access journal focusing on the pathological basis of all cancers, potential targets for therapy and treatment protocols employed to improve the management of cancer patients. The journal also focuses on the impact of management programs and new therapeutic agents and protocols on patient perspectives such as quality of life, adherence and satisfaction. The manuscript management system is completely online and includes a very quick and fair peer-review system, which is all easy to use. Visit http://www.dovepress.com/ testimonials.php to read real quotes from published authors 